\title{
Crowding out or Knowledge Spillovers from the Wind Power Industry: The Effect on Related Energy Machinery
}

\author{
JONAS GRAFSTRÖM* \\ The Ratio Institute and Luleå University of Technology \\ SE-113 59 Stockholm \\ Sweden \\ E-mail: jonas.grafstrom@ratio.se
}

\begin{abstract}
There is a risk that if a government adopts a R\&D spending policy directed towards wind power technology crowding out of other technologies might occur due to fiscal constraints and changes in relative prices. The purpose of this paper is to provide a backward-looking analysis of how the accumulation of wind energy patents and public R\&D spending affected the domestic and neighboring country output of granted patents in the "related energy machinery field". The econometric analysis, a Poisson fixed-effects estimator based on the Hausman, Hall and Griliches (1984) method, relies on a data set consisting of eight countries in Western Europe with the highest rates of patent production in the field of wind power between 1978 and 2008. The results show that an accumulation of a national wind power stock is a statistically significant negative determinant of a country's related energy machinery patenting outcomes. However, no crowding out effects of public R\&D spending were found.
\end{abstract}

Keywords: knowledge spillovers, wind power, R\&D, patents, renewable energy, innovation. JEL classification: E61, O32, Q2, Q58.

\footnotetext{
* Financial support from The Ratio Institute as are valuable comments and help from Anders Gustafsson and Daniel Halvarsson. This paper has been presented at the 41st IAEE International Conference in Groningen 2018. Responsibility for any remaining errors, however, resides solely with the author.
} 


\section{Introduction}

There is an increasing interest in assessing the effects of wind power R\&D policies which plays an important role in stimulating innovation in the wind power sector (De Vries and Withagen, 2005; Johnson and Lybecker, 2012; and Johnstone, Hascic, and Popp, 2010). The aphorism "a rising tide lifts all boats" is associated with the idea that the improvements for some will eventually lift everyone else up as well. ${ }^{1}$ The aphorism suggests an argument for public R\&D spending in renewable energy technologies where the spending will enhance, and hence lift up, other technologies through knowledge spillovers (see e.g., Cohen and Levinthal, 1989; Hussler, 2004; Antonelli, 2008; Costantini and Crespi, 2008a; Antonelli and Quatraro, 2010).

However, while knowledge spillovers can have both a positive and negative effect there are potential under-investigated downsides with public R\&D policies: crowding out effects are such downsides. The presence or absence of knowledge spillover (and possible crowding out effects) are likely to influence government policies on R\&D spending (e.g., Söderholm and Sundqvist, 2007; Peters et al., 2012). There are incentives for national governments to be the second mover and free-ride on others' efforts (Fischer, 2008; Jaffe, Newell, and Stavins, 2005; Popp, 2005). Private firms have, to some extent, also weak incentives to make R\&D investments (Jaffe, Newell and Stavins, 2005; Acemoglu, Aghion, Bursztyn, and Hemous, 2012, Aalbers, Shestalova, and Kocsis, 2013).

The purpose of this paper is to provide a backward-looking ${ }^{2}$ analysis of how the accumulation of wind energy patents and public R\&D spending affected the domestic and neighboring country output of granted patents, ${ }^{3}$ in the related energy machinery field (i.e., energy machinery closely related to wind energy machinery ${ }^{4}$ ). Specifically, the paper investigates how the

\footnotetext{
${ }^{1}$ The phrase is commonly attributed to a speech where John F. Kennedy was defending an infrastructure spending project against criticism of that it was a pork barrel project. However, according to Kennedy's speechwriter Ted Sorensen the phrase was actually taken from a thoughtful slogan presented by the regional chamber of commerce, the New England Council (Sorensen, 2008).

${ }^{2}$ This to complement previous knowledge spillover studies in the wind power sector. As more data become available over time it will be highly interesting and important to study the more present-day development i.e., after year 2000 when the technological development within wind power started to accelerate.

${ }^{3}$ The motivation for only considering granted, and not also applications, is that it gives the research a qualitative edge since only approximately half of all patent applications submitted to, for example, the European Patent Office (EPO) are in fact granted (Battistelli, 2011). There is, of course, a pro et contra decision to be made: since this paper concerns invention outcomes, granted patents data will be used. The intellectual property right is protected from the priority year and the priority year is also closer to the date of 'invention' and hence that date is used.

${ }^{4}$ The IPC class "F03D", covers $96 \%$ of all wind power patents according to Keefe (2010). The class "F03D" belongs to the wider industrial field "energy machinery" (i.e., machines or engines for liquids; wind, spring or weight motors; producing mechanical power or a reactive propulsive thrust, not otherwise provided for). Combustion engines are, for example, not included in what we refer to as the related industries.
} 
accumulation of wind energy patents and public R\&D spending affected the output of domestic granted related energy machinery patents production and neighboring countries (see figure 1). By doing the above we capture the presence of inter-industry spillover towards other energy machinery fields close to wind power. To our knowledge there are few spillover and R\&D crowding out studies on renewable energy in general, and on wind power in particular.

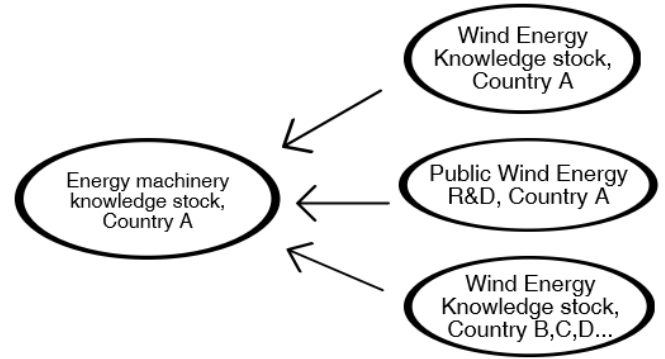

Figure 1. Spillover effect to related industries and R\&D efforts

Based on the reasoning above, this paper seeks to expand the existing literature dealing with inter-country knowledge spillovers. ${ }^{5}$ The spillover literature concentrates on within-industryspillovers, not inter-industry spillovers (see, e.g, Klaassen et al., 2005; Mancusi, 2008; Aldieri and Cincera, 2009; Braun 2011; Corradini et al., 2014; Lehmann, 2013; Grafström 2018; Grafström and Lindman 2017) with an exception of Nemet (2012) who investigate interindustry knowledge spillovers by investigating patent citations.

The paper therefore adds to the existing literature in the sense that: (a) our understanding of spillovers are enhanced from cross-country to inter- industry; (b) potential crowding out effects of government R\&D spending is investigated; (c) increase the understanding of the early phase of a technology, something that will be important for less developed climate mitigating technologies such Carbon Capture and Storage technologies and (d), we discuss the implications of our analysis for the literature on knowledge spillovers, and, more generally, on technological evolution, as well as for technology policy relating to governmental $\mathrm{R} \& \mathrm{D}$ spending decisions. Two questions are considered:

- Are there knowledge spillovers originating in the wind power field that have a positive effect on closely related technology fields i.e., will R\&D investment in wind power machinery enhance the output of other energy machinery as well?

\footnotetext{
${ }^{5}$ Our focus on the wind power industry case in Europe is worthwhile based on the observations that: (a) wind power represents a key energy technology for countries that wish to build-up an energy mix that can comply with existing European climate policy targets (e.g., Söderholm and Sundqvist, 2007); (b) the development of modern wind power technology in Europe is largely concentrated to a few countries.
} 
- Are there crowding out effects caused by $R \& D$ spending i.e., will $R \& D$ spending directed towards the wind power field have negative effect on related energy fields?

The econometric analysis relies on a data set consisting of eight countries in Western Europe with the highest rates of patent production in the field of wind power between 1978 and $2008 .^{6}$ The motivation for excluding several countries is that after investigating at the patent and $R \& D$ data for the respective countries it was rather clear that patents and R\&D spending was limited in most of the countries, i.e., inactivity within wind power research. ${ }^{7}$

To analyze the data set, a Poisson fixed-effects estimator regression model is used since the model allow for count data it is based on the Hausman, Hall and Griliches (1984) method. To empirically investigate the two posed questions a so-called knowledge production function is estimated; the rate of new knowledge creation is assumed to depend on, for instance, the amount of labor engaged in $R \& D$ and the patents-based stock of knowledge available to these researchers (e.g., Ibenholt, 2002; Klaassen et al., 2005; Krammer, 2009; Söderholm and Klaassen, 2007; Joutz and Abdih, 2005).

In general, for our purposes a technological knowledge stock reflects the cumulative technological knowledge that a country possesses at a given point in time (e.g., Klaassen et al., 2005; Antonelli et al. 2011; Boschma and Iammarino, 2009; Corradini et al., 2014, 2015; Park and Park 2003, 2006). A positive correlation between a knowledge stock and technological output (granted patents) is interpreted as a sign of knowledge spillovers. ${ }^{8}$ The knowledge stocks represent the accumulation of granted wind power- and related energy machinery patents from international and domestic sources, and have been constructed using the perpetual inventory method (Ek and Söderholm, 2010).

From a general policy perspective, the necessity (sooner than later) for R\&D spending on renewable energy stems from the fact that the anthropogenic emissions of greenhouse gases (GHGs) now above 400 parts per million ( $\mathrm{ppm}$ ) compared to a historical value around $250 \mathrm{ppm}$

\footnotetext{
${ }^{6}$ Priority date is used, additional robustness test with other time periods were also tested.

${ }^{7}$ The decision to focus on spillovers within the EU is motivated by the fact that the EU has set renewable energy targets, and that spillovers and the consequences of spillovers will be important for the chance of success for these targets. Even though there are patent data available on all OECD as well as non-OECD countries, not all countries' data will be used as there is only marginal patent activity - if it even exists - in many of these. For instance, between 1978 and 2008, the number of wind power patent applications in several OECD countries only amounted to about one a year.

${ }^{8}$ There is of course a concern that innovation in wind power technology does not only manifest by patents in the F03D group, but that a lot of complementary innovation is carried out in precisely these related technological fields. However, according to a study by the UK's Intellectual Property Office, the F03D (wind power) classification covers $96 \%$ of all wind power patents (Keefe, 2010; Dechezleprêtre and Glachant, 2014). The technologies are further identified as related but not supporting technologies, there is a possibility that a firm carry out R\&D in several fields, but the number should not be that many.
} 
(EPA, 2016) have a distinct impact on the global climate (e.g., IPCC, 2007, 2013). Although carbon dioxide $\left(\mathrm{CO}_{2}\right)$ is a normal component in our atmosphere, and has made life on earth possible in the first place, the increased concentrations may change our climate in ways that present a critical mix of dangers (e.g., changed weather patterns with increased variability, rising sea levels and droughts (Dietz and Maddison, 2009; Suganthi and Samuel, 2012). One way to sustain a status-quo for the global climate and limit the concentrations of GHGs is to develop and diffuse new carbon-free or low carbon technologies, not the least in the form of renewable energy sources (Stern, 2007).

The remainder of the paper is organized as follows. Section 2 introduces three important concepts regarding knowledge spillovers. Section 3 presents the model specification and discuses some important econometric issues, while section 4 provides a description of the data definitions and sources. Section 5 reports on the results from the different empirical specifications, while section 6 synthesizes the empirical findings and discusses the results. Section 7 contains the conclusions and policy implications.

\section{Spillovers - The Spread of Innovation and Knowledge}

In this section, three conceptual topics that are important for the paper will be presented and discussed. Specifically, these three concepts are: (a) General and Renewable Energy Technological Knowledge Spillovers; (b) Inter-industry Knowledge Spillovers; and (c) Public $R \& D$ spending crowding out effects, here commented on in more detail with reference to relevant research done in the renewable energy sector.

\subsection{General and Renewable Energy Technological Knowledge Spillovers}

Technological change is imperative for economic development (Schumpeter, 1934). In a letter written by Isaac Newton year 1676 the phrase "If I have seen further it is by standing on ye sholders of Giants" was coined. The phrase can roughly be translated to: gains in science builds on previous findings. Following Newton's insight; a key characteristic of technological change is that technological innovation builds upon prior existing knowledge and the ability to absorb new knowledge (Dosi, 1982; Aldieri and Cincera, 2009; Mancusi, 2008).

Technological change is frequently, but not always, shaped by problem solving within a technological field; building on and expanding knowledge from the same technology. However, knowledge spillovers across technologies also occur (Cohen and Levinthal, 1990; Lazear, 2004; Lettl et al. 2009; Nemet, 2012; Nemet and Johnson, 2012; Noailly and Shestalova 2013). Consequently, knowledge flows mostly within the same technology but have the potential to 
reinforce other knowledge generating processes and create spillovers across technologies and thus increase technological variety (van den Bergh, 2008; Schoenmakers and Duysters, 2010).

In the renewable energy sector, the empirical evidence for the existence of international knowledge spillovers is still limited. Peters et al. (2012) found evidence of public policy-related spillovers in the solar PV industry. In addition, Dechezleprêtre, Martin, and Mohnen (2013) compared the intensity of patent citations in clean energy with their less-clean counterparts and found that clean energy patents are cited more frequently than patents based on less-clean technologies, possibly indicating more knowledge spillovers in the former sector. Furthermore, Poirier et al. (2015) estimated a knowledge production function, and analyzed the effect of international co-authorship of scientific publications on patenting in wind energy technologies within the OECD and the non-OECD countries. Their results suggest that there exist knowledge spillovers between these country groups (see figure 2). Braun et al. (2011) studied solar and wind power finding no knowledge spillover effects between 21 OECD countries between 1978 and 2004. Grafström and Lindman (2017) and Grafström (2018) found evidence of knowledge spillovers in the wind sector.
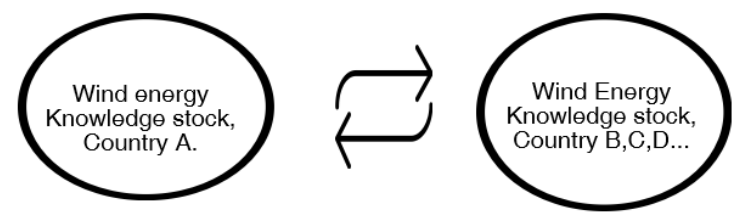

Figure 2 Country spillovers between countries

Our empirical work is related to the literature which are using patent counts to measure inventions and innovation in renewable energy technologies (Popp, 2002; Dekker, Vollebergh, de Vries, and Withagen, 2012; Johnstone and Haščič, 2010; Braun et al., 2011; Grafström and Lindman 2017; and Grafström, 2017). ${ }^{9}$ Using patent data covering in eleven different energy technologies, Popp (2002) finds evidence for significant intra-technology knowledge spillovers. Johnstone and Haščič (2010) also find inter-technology spillovers, showing that previous

\footnotetext{
${ }^{9}$ Most studies that have concerned environmentally related patents have rather focused on how public policies affect innovative activity. Johnstone et al. (2012) investigated the determinants of environmentally related patents (e.g., for wind and solar power), and found that both general innovative capacity and environmental policy stringency have played positive roles in environment related innovation. Johnstone et al. (2010) found that different policies are better or less well-suited with regard to inducing innovations. De Vries and Withagen (2005) use environmentally related patents in Europe as environmental innovation indicators. They measure policy stringency, with an underlying idea about a connection between high emission levels, which trigger strict environmental policy, thus creating stronger incentives for innovation.
} 
knowledge accumulated in storage technologies positively affect innovation in other clean technologies. ${ }^{10}$

A, too this paper, closely related study was performed by Noailly and Shestalova (2013) who investigate spillovers but define spillovers to technologies unrelated to power-generation as external-technology spillovers. Corradini et al. (2014) studied how firms and sectors in 15 European Union (EU) countries and 23 manufacturing sectors had been affected by environmental protection decisions in other firms, sectors or countries. They focused on the time period 1995-2006 and applied a similar modeling strategy as in this paper i.e., a knowledge stock approach including also geographic weighting to account for distance effects. ${ }^{11}$

\subsection{Inter-industry Knowledge Spillovers}

Within the technological change literature, an important concept is that novel technologies are a product of near and distant technologies that have been combined. Consequently, gains in existing technologies can be transferred to the same or different technology fields, i.e., knowledge flows within and across technologies. Previous literature on technological change has underlined the significance of the cumulative character of knowledge for the expansion of further technological change (Griliches 1979, 1992; Antonelli 2008; Costantini and Crespi 2008a, 2008b). Usually, knowledge produced within a technology positively affect further development within the same technology.

However, knowledge spillovers across seemingly unrelated technologies also occur, i.e., technologies can benefit from knowledge that originated in other distant technologies (Cohen and Levinthal, 1990; Lazear, 2004; Lettl et al. 2009; Nemet 2012; Nemet and Johnson, 2012; Noailly and Shestalova 2013; Schoenmakers and Duysters, 2010). Hence, intra-technology spillovers motivate support for technological variety where unforeseen effects can have a big and positive impact on the general development and can therefore be one potential goal of technology policy (Battke, Schmidt, Stollenwerk, and Hoffmann, 2016).

\footnotetext{
${ }^{10}$ Another approach to measuring knowledge spillovers is to follow the paper trail of citations: if one wants to be awarded a patent, one needs to cite other relevant research.

11 There are other studies (focused on the firm level) that have investigated knowledge spillovers, and the determinants of renewable energy patents. For example, Aldieri and Cincera (2009) used the knowledge-stock approach to study spillovers between large international R\&D companies' productivity growth. Corradini et al. (2015) studied firms' decision to invest in innovation in the context of impure (or mixed) public good provision using a knowledge stock and found that the positive correlation between environmental and innovation performances might be reinforced by different spillover mechanisms.
} 
According to Nemet (2012) the indications of inter-technology knowledge spillovers is broad, if anecdotal. Several advances have lead the way for largely unrelated sectors. An example where the energy sector was positively affected is when jet engines for military aircraft provide the fundamental technology for high efficiency natural gas power plants. General Electric's LM6000 50MW gas turbine is directly descended from the TF39 high-bypass turbo-fan engine, developed in the 1960s. The wind turbines of today are a product of knowledge from other industries, especially marine, but also aerospace and electronics. For example, knowledge from pipe building, magnet manufacturing, and marine propulsion was necessary for the upscaling of wind turbines. Nemet (2012) showed that in the energy technology case the knowledge spillovers are stronger for technologically distant prior art (i.e., diversified knowledge) than the spillovers to technologically near prior art (i.e., inter-technology).

The previous technological spillover literature concerning renewable energy did not focus on whether knowledge flows remain within the same technology or whether the knowledge was transferred to different technologies in the form of knowledge spillovers. One exception is Noailly and Shestalova (2013) who presented a discussion paper that differentiates knowledge flows within and across technologies. In contrast to this view, there are studies which suggest that intra-technology is more likely to generate knowledge flows since "learning performance is greatest when the object of learning is related to what is already known" (Cohen and Levinthal, 1990, p. 131). Lettl et al. (2009, p. 246) argue that "specialization is [thus] positively associated with technological impact." Following this line of reasoning, inter-technology, which is typically based on technologically near areas (Lazear, 2004; Lettl et al., 2009), can be expected to generate a higher amount of knowledge flows.

\subsection{Crowding out effects from Public R\&D spending}

The basic rationale for public support to $R \& D$ is well-established ${ }^{12}$ where a large body of literature has argued that the market can fail in providing the socially efficient amount of resources aimed at generating new technological and scientific knowledge (e.g., Nelson, 1959; Arrow, 1962; Guellec and Pottlesberg, 1997, 2003). The failure steams from positive externalities (i.e., spillovers) where new knowledge generation often has strong public good characteristics, leading to free-riding on others' development efforts (e.g., Mansfield, 1977). However, many have pointed out that public environmental R\&D subsidies seldom achieve in

\footnotetext{
${ }^{12}$ There is however a discussion of the effectiveness of public R\&D programs see e.g., Jaffe 2002 and Hall 2002.
} 
improving the environment by themselves (Schneider and Goulder 1997; Jaffe et al. 2004; Fischer and Newell 2004; Popp 2006) and an ongoing discussion of the effectiveness of public R\&D programs (see e.g., Jaffe, 2002 and Hall, 2002).

Previous research has also indicated that the $R \& D$ underinvestment problem may be particularly prevalent in the case of $R \& D$ targeting environmental technology and clean energy; due to the particularly strong presence of knowledge spillovers across firms and countries in these sectors (e.g., Popp, 2005; Fischer, 2008; Peters et al., 2012; Dechezleprêtre et al., 2013). Moreover, uncertainties about the future returns to environmental R\&D tend to be especially high, e.g., because of policy inconsistencies (Jaffe et al., 2002). From a public economics perspective, a higher provision of dual types of public goods, i.e., a cleaner environment following pollution abatement and improvements in new clean energy technology, by some countries could lead to shrinking incentives for other countries to pursue similar efforts.

Failing to account for opportunity cost of renewable energy R\&D investments may affect the accuracy of future policy models when dealing with climate change (Popp and Newell, 2012). There is a short run constraint on available $R \& D$ money - any new renewable energy $R \& D$ compete with other R\&D investment (e.g., Nordhaus (2002) assumes a fixed supply of R\&D labor). Hence, the question of whether renewable energy R\&D represents new R\&D spending, or whether some (or all) of the additional renewable energy R\&D comes at the expense of another R\&D i.e., crowding out. Over time there have been an increase in public renewable energy R\&D possibly crowding out research funding from other productive sectors (Popp, 2006; Schneider and Goulder, 1997; Yang and Oppenheimer, 2007 and Popp and Newell, 2012).

The supply-side of research capital might not be the only cause. We might see a result of rational, profit maximizing firms transferring $R \& D$ resources from opportunities that become less profitable as energy prices changes. Busom (2000) found that public funding induces more private effort, but for some firms (30\% of participants) full crowding out effects could not be ruled out. The result of firm level R\&D studies are mixed where for example Antonelli (1989) found a positive elasticity of private funded $R \& D$ with respect to the public $R \& D$ subsidy.

There has been limited empirical work addressing the magnitude of potential national crowding out effects within the renewable energy field. Link (1982), found evidence of R\&D productivity decline in the 1970s due to allocation of R\&D toward environmental research, whose benefits (e.g. a cleaner environment) were not measured in traditional market outcomes. On a macro level, Nemet and Kammen (2007) find little evidence of crowding out from public energy R\&D 
spending. However, on a firm level of Austria, Roediger-Schluga (2003) found that most firm's re-schedule $R \& D$ projects in order to increase environmental $R \& D$ after passage of new volatile organic compound standards.

\section{Model Specifications and Econometric Issues}

\subsection{Model Specification}

The empirical approach for assessing spillovers and crowding out effects is performed by studying how flow- and knowledge stock variables, the accumulation of knowledge, in one country affects inventive output in other countries. The approach stems from various previous studies (e.g., Klaassen et al., 2005; Antonelli et al. 2011; Boschma and Iammarino 2009; Corradini et al., 2014). The baseline setting for the empirical part is presented in equation (1), a production function of patents commonly encountered in the literature is presented:

$$
P C_{n t}=\beta_{0}+\beta_{1} R E S_{n t-3}+\beta_{2} R \& D_{n t-3}+\beta_{3} \mathrm{~K}_{n t}+\alpha_{n}+T_{n}+\varepsilon_{n t},
$$

where the dependent variable, $P C_{n t}$, is a count of to wind power related energy machinery patents in country $n(n=1, \ldots, N)$ for a given year $t(t=1, \ldots, T)$ i.e., the year the granted patent had its priority year. Public wind power $\mathrm{R} \& \mathrm{D}$ expenditures $\left(R \& D_{n t}\right)$ is used to estimate if there are any crowding out effects. The number of researchers per capita $\left(R E S_{n t}\right)$ are a control variable for general level of research output capacity in the country; these two control variables are lagged three years. For example, public R\&D expenditures taking place in period $t$ may lead to a patent application and, eventually, to a patent being granted no earlier than in period $t+x(x$ = 3) (Nicolli et al., 2012). $K_{n t}$ is a domestic wind power patent-based knowledge stock in country $n$ in period $t$. In the based model (equation 1), each country's separate knowledge stock consists of an accumulation of previously assembled wind power patents in that country, here denoted as the national knowledge stock. Moreover, the patent-based stocks are constructed with a three-year lag and a 15 percent depreciation rate (see further section 4).

Country-specific fixed effects, $\alpha_{n}$, are introduced to capture any unobservable country-specific heterogeneity. Time dummies, $\mathrm{T}_{\mathrm{n}}$, are also included. The econometric analysis includes time dummies, and therefore a concern is remedied - that the coefficients on the variables of interest capture shocks correlated with both the level of R\&D policies and the knowledge stocks, and innovation activity. This could include any macroeconomic shocks and one can think plenty of such unobserved variables that may cause the coefficients to be strongly biased. All the residual variation is captured by the error term, $\varepsilon_{n t}$. 
Model I presented in equation (1) is the baseline upon which eight additional model specifications (II-VIII) will be built. The time periods 1978-2008 and 1990-2008 is tested for the specifications. The different specifications (Models I-VIII) of the patent production model are presented in Table 1.

Table 1: Patent production model specifications

\begin{tabular}{|c|c|c|}
\hline Model & Estimated model specification & Description \\
\hline I & $P C_{n t}=\beta_{0}+\beta_{1} R E S_{n t-2}+\beta_{2} R \& D_{n t-2}+\beta_{3} K_{n t}+\alpha_{n}+\varepsilon_{n t}$ & $\begin{array}{l}\text { Base model with national } \\
\text { knowledge stock and R\&D } \\
\text { flow } 1978-2008 \text {. }\end{array}$ \\
\hline II & $P C_{n t}=\beta_{0}+\beta_{1} R E S_{n t-2}+\beta_{2} R \& D_{n t-2}+\beta_{3} D I K_{n t}+\alpha_{n}+\mu_{n t}$ & $\begin{array}{l}\text { Distance-weighted } \\
\text { international knowledge } \\
\text { stock and R\&D flow 1978- } \\
2008 \text {. }\end{array}$ \\
\hline III & $P C_{n t}=\beta_{0}+\beta_{1} R E S_{n t-2}+\beta_{2} R \& D_{n t-2}+\beta_{3} K_{n t}+\alpha_{n}+\eta_{n t}$ & $\begin{array}{l}\text { Base model with national } \\
\text { knowledge stock and R\&D } \\
\text { flow 1990-2008. }\end{array}$ \\
\hline IV & $P C_{n t}=\beta_{0}+\beta_{1} R E S_{n t-2}+\beta_{2} R \& D_{n t-2}+\beta_{3} D I K_{n t}+\alpha_{n}+v_{n t}$ & $\begin{array}{l}\text { Distance-weighted } \\
\text { international knowledge } \\
\text { stock and R\&D flow 1990- } \\
2008 \text {. }\end{array}$ \\
\hline $\mathrm{V}$ & $P C_{n t}=\beta_{0}+\beta_{1} R E S_{n t-2}+\beta_{2} R \& D S_{n t-2}+\beta_{3} K_{n t}+\alpha_{n}+v_{n t}$ & $\begin{array}{l}\text { Base model with national } \\
\text { knowledge stock and R\&D- } \\
\text { Stock 1978-2008. }\end{array}$ \\
\hline VI & $P C_{n t}=\beta_{0}+\beta_{1} R E S_{n t-2}+\beta_{2} R \& D S_{n t-2}+\beta_{3} D I K_{n t}+\alpha_{n}+\lambda_{n t}$ & $\begin{array}{l}\text { Distance-weighted } \\
\text { international knowledge } \\
\text { stock and R\&D-Stock } \\
1978-2008 .\end{array}$ \\
\hline VII & $P C_{n t}=\beta_{0}+\beta_{1} R E S_{n t-2}+\beta_{2} R \& D S_{n t-2}+\beta_{3} K_{n t}+\alpha_{n}+\phi_{n t}$ & $\begin{array}{l}\text { Base model with national } \\
\text { knowledge stock and R\&D- } \\
\text { Stock 1990-2008. }\end{array}$ \\
\hline VIII & $P C_{n t}=\beta_{0}+\beta_{1} R E S_{n t-2}+\beta_{2} R \& D S_{n t-2}+\beta_{3} D I K_{n t}+\alpha_{n}+\rho_{n t}$ & $\begin{array}{l}\text { Distance-weighted } \\
\text { international knowledge } \\
\text { stock and R\&D-Stock } \\
\text { 1990-2008. }\end{array}$ \\
\hline
\end{tabular}

Models I-IV analyze the presence of knowledge spillovers originating in the wind power field, including the role of international wind power knowledge spillovers. A positive statistically significant result would indicate knowledge spillovers while a negative statistically significant sign would indicate a crowding out effect. Furthermore, the same approach holds for the R\&D variable. Model V-VIII investigates how different aspects of R\&D crowding out has affected energy machinery patenting output. 
Specifically, Model II includes the distance weighted international patent-based knowledge stock $\left(D I K_{n t}\right)$, the accumulated stock minus the domestic stock for each country. Model II aims to test whether knowledge accumulation (in the form of a patent stock) affects the creation of wind power patents in a neighboring country. A distance weighting is applied to the international knowledge stock in order to determine if geographic distance affects spillovers. The patent knowledge stock is weighted based on the inverse exponential distance between countries. Model III test the same variables as Model I but during the period 1990-2008. Model IV mirrors Model II but also for the period 1990-2008. Models V-VIII address the same set up as Model I-IV but consider the public R\&D spending as a stock variable.

\subsection{Econometric Issues}

Patent data are of a binomial nature; thus, the dependent variable will have a count nature (e.g., Baltagi, 2008; Greene, 2012). For these types of count data regressions, either a negative binomial or Poisson estimators should be applied (Hausman et al., 1984). A Poisson fixedeffects estimator will be used. There is some general criticism against the model choice that will be presented and a rebuttal.

The Poisson model has been criticized in the count panel data literature for its assumption that the variance is equal to its mean i.e., equi-dispersion. Thus, the Poisson distribution is often rejected in favor of models accommodating over-dispersion, i.e., where the variance is larger than the mean. The problem with the traditional Poisson distribution, which assumes equidispersion, is that the results contain incorrect standard errors of the parameter estimates. To model over-dispersion, therefore, the negative binominal specification is usually employed (e.g., Baltagi, 2008). The negative binominal specification modification relaxes the Poisson assumption (Greene, 2012). ${ }^{13}$

However, some have argued that the conditional fixed effects negative binomial estimator available in Stata (xtnbreg) should be avoided, since it is not a true fixed-effects estimator (see Allison and Waterman 2002; Greene 2007). A remedy is using the Poisson fixed-effects estimator based on the Hausman, Hall and Griliches (1984) method (the count data equivalent to the within groups estimator), available in Stata as xtpoisson. Contrary to what is commonly claimed, Poisson models estimated by pseudo-maximum likelihood as is the case in Stata are perfectly capable of dealing with both under and over-dispersion, as is explained by Santos

\footnotetext{
${ }^{13}$ The Wald chi-square statistic, with 32 degrees of freedom for the full model, was performed as well. This test whether all of the estimated coefficients are equal to 0 , i.e. a test of the models as a whole, with all explanatory variables. From the p-value, it was concluded that the models are statistically significant.
} 
Silva and Tenreyro, (2006). Hence, the negative binomial models offer no particular advantage. ${ }^{14}$

\section{Data Sources and Definitions}

\subsection{The Dependent Variable}

The dependent variable, granted patent applications (priority year is used) in related industries, steams from the classification on renewable energy technologies by Johnstone et al. (2010) is combined with a sectorial concordance provided by Schmoch et al. (2003) that links industrial fields to IPC classes. Based on this concordance, we identify those fields that encompass the IPC classes defining innovation in wind technology and denote them as being related to wind energy. According to Johnstone et al. (2010), patents with IPC class "F03D" belong to the field of wind energy. The class "F03D" belongs to the industrial field "energy machinery." To derive the patent stock in what we denote the related energy machinery field we sum the granted applications belonging to the "energy machinery" field and subtract those belonging to F03D. There is an obvious critic against the choice of data for a patent study but for this particular study the data is suitable. Alternative sources for selecting patent data in the wind power sector have become available beside the Green Inventory classification. E.g., IPC and EPO Y02E10/70 Cooperative Patent Classification class or the OECD ENVTECH Indicator. (See e.g., OECD, (2015) for an in-depth general discussion or Costantini et al, (2015b) for a discussion about the pro et contra of the different data selection systems and a keyword-based methodology for patent analysis which was applied to the biofuels). Lybbert and Zolas (2014) recently developed 'probabilistic' concordance this 'Algorithmic Links with Probabilities' (ALP) approach incorporates text analysis software and keyword extraction programs and applies them to a comprehensive patent dataset. However, this method had some problems with more general patent searchers like "Non-specific Machinery" and "Agricultural machinery" and since a large part of the relating energy machinery could suffer from the same problem the approach by Schmoch et al. (2003) was used.

The Green Inventory Classification (GIC) was chosen to enable study of inter-sectorial spillovers between other energy machineries. In many of the other renewable energy classes the GIC did not capture all relevant patents. However, according to a study by the UK's Intellectual Property Office, the F03D (wind power) classification covers 96 percent of all wind

\footnotetext{
${ }^{14}$ If a negative binomial model is used, an unconditional negative binomial estimator with both country and time dummies is far more preferable than the xtnbreg model.
} 
power patents (Keefe, 2010; Dechezleprêtre and Glachant, 2014). The justification of using the current patent classification regime lies in its comparability with the related industries patents variable that is used in the attempt to identify cross sector knowledge spillovers.

The source of the patent data was the OECD Patent Database. ${ }^{15}$ The patent system is constructed using a hierarchy of levels as described in Table 2.

Table 2: General structure of the International Patent Classification (IPC) system

\begin{tabular}{|l|l|l|}
\hline $\begin{array}{l}\text { Hierarchical } \\
\text { level }\end{array}$ & $\begin{array}{l}\text { Classification } \\
\text { symbol }\end{array}$ & Classification title \\
\hline Section & F & Mechanical engineering; lighting; heating; weapons; blasting \\
\hline Subsection & F0 & Engines or pumps \\
\hline Class & F03 & $\begin{array}{l}\text { Machines or engines for liquids; wind, spring or weight motors; } \\
\text { producing mechanical power or a reactive propulsive thrust, not } \\
\text { otherwise provided for. }\end{array}$ \\
\hline Subclass & F03D & $\begin{array}{l}\text { Wind motors } \\
\text { This subclass covers wind motors, i.e. mechanisms for converting the } \\
\text { energy of natural wind into useful mechanical power, and the } \\
\text { transmission of such power to its point of use. }\end{array}$ \\
\hline Main group & F03D 1/00 & $\begin{array}{l}\text { Wind motors with rotation axis substantially in wind direction } \\
\text { (controlling F03D 7/00) }\end{array}$ \\
\hline Subgroup & F03D 7/00 & \begin{tabular}{l} 
Controlling wind motors \\
\hline
\end{tabular} \\
\hline
\end{tabular}

Hence, we are given the following patent cases based on work by Johnstone et al. (2010) and Schmoch et al. (2003) as displayed in table 2

Table 2: Related wind technology

\begin{tabular}{|l|l|l|}
\hline Field & IPC Classes & Except for wind technology IPC Class \\
\hline Energy machinery & B23F, F01B, F01C, F01D, F03B, & F03D \\
& F03C, F03D, F03G, F04B, F04C, & \\
& F04D, F15B, F16C, F16D, F16F, & \\
& F16H, F16K, F16M, F23R & \\
\hline
\end{tabular}

The geographical location of the inventor rather than that of the formal applicant was used. The applicant (e.g., a firm) can be an entity registered in a locality that is not the same as where the

\footnotetext{
${ }^{15}$ The OECD data is in turn, derived from the EPO's Worldwide Patent Statistical Database (PATSTAT).
} 
knowledge was actually produced (e.g., Fischer et al., 2006). When patents were awarded to multiple inventors from different countries the count has been split. ${ }^{16}$

Beside the selection of patent data type to use a comment of the use of patent data as a proxy for technological development is required. Patents are to a large extent internationally standardized, (Rübbelke and Weiss, 2011). Moreover, it is hard to get a patent application approved: basically, several prerequisites are required were a patent must be: 'novel', 'useful', and 'non-obvious', and that has an inventive step. Failure to meet these criterions meant that a patent cannot be awarded (Griliches 1987; Hall and Ziedonis, 2001). To enable more accurate comparisons within the data set, the study used patents granted by the EPO rather than those granted by the respective countries' own patent offices because the latter all vary in their patenting rules (Eaton and Kortum, 1999; Fischer, 2013).

Moreover, there are conceptual criticisms against the use of patent data as a measure of invention output. For example: all new inventions are patented, and patents differ greatly in their economic impacts (Pakes and Griliches, 1980, 378). Furthermore, the economic value of some patents is much smaller than other, in most cases a few percent of the patents capture almost all benefits or become economically worthless within a relatively short period (Pakes, 1985; Schankerman and Pakes, 1987; Scherer and Harhoff, 2000). Furthermore, a patent is a strategic tool, i.e. it can be sold, withheld or offered by way of licensed use to others (Cohen et al., 2000). All inventions are certainly not patented, the reasons vary, and one may be that small firms find the application process difficult; as a result, they may not bother submitting an application (Adams, 2005). Instead, firms may use various types of confidentiality to conceal their production procedures (Cohen et al., 2000; Trajtenberg, 2001).

Nonetheless, even with all their potential flaws, patenting records remain a good - possibly even the best - available quantitative source for assessing technological changes and innovation. As Griliches $(1998,336)$ puts it, 'nothing else comes close in quantity of available data, accessibility and the potential industrial organizational and technological details'.

\subsection{The Independent Variables}

Following economic theory, the invention capabilities of a country are considered to depend fundamentally on three factors: (a) its invention infrastructure such as R\&D employees or R\&D

\footnotetext{
${ }^{16}$ To handle fractionalization of the variable in the count data setting, the patents were rounded off to the nearest integer number. For example, a patent jointly registered by two inventors - one Swedish and one German - was counted as 0.5 patents for each of the countries concerned in the retrieved data.
} 
expenditures as well as the stock of previous innovations (e.g. Romer, 1990; Grossman and Helpman, 1991); (b) its technological and economic specialization (Archibugi and Coco, 2005), and (c) the quality of the linkages between its common infrastructure and those industries (Jungmittag, 2006).

The $R \& D$ and $R \& D S$ variable represents a flow and stock variable of government expenditure on wind energy R\&D in million USD (2012 prices). General- and specific purpose R\&D is commonly considered and used as a variable when analyzing a country's inventive capacity (e.g. Romer, 1990; Grossman and Helpman, 1991; Dechezleprêtre et al., 2013; Furman, Porter, and Stern, 2002). The data derive from the International Energy Agency. ${ }^{17}$ These IEA data are known as a premium accessible data source of public $R \& D$ expenditures in the energy sector (Garrone and Grilli, 2010).

Despite IEA is a good data source, it does not mean that the data are free from complications (Bointner, 2014). For example, it has been argued that the database represents an incomplete representation of public support to energy R\&D (e.g., Arundel and Kemp, 2009). There are also consistency issues with respect to the geographical coverage. For instance, Germany was reunified in 1991 but reports some missing data for the new Bundesländer (i.e., states formerly part of the German Democratic Republic) prior to 1992. Also, not all countries provide R\&D data funded by regional governments (IEA, 2012). R\&D data from the private sector would have been both important and interesting to include, but a comprehensive form of such data was not available. Public R\&D funding spent on wind power has frequently been used to explain different aspects of technological change in the wind power industry (e.g., Ibenholt, 2002; Klaassen et al., 2005; Krammer, 2009; Söderholm and Klaassen, 2007).

Public R\&D support is not the only channels for public support for individual firms; there are tax incentives, direct government funding, co-operation arrangements between firms, research institutes and universities, and loan guarantees. Hence, a weakness with this study is that it does not consider these effects. Public founding spent on R\&D within the wind power field was used as an overall variable for a government's willingness to support the development of wind power. $^{18}$

\footnotetext{
${ }^{17}$ We could not distinguish between R\&D expenditures for onshore and offshore wind power.

${ }^{18}$ Policy schemes have been implemented in the selected countries and research has been done on their outcomes. The introduction of policy support and new environmental regulations has been revealed to be an R\&D stimulus since policy can affect market conditions by giving rise to new profit opportunities (e.g. Arent, Wise, and Gelman 2011; Fischer, Scherngell, and Jansenberger 2009; Ibenholt 2002; Klaassen et al. 2005; Sterner and Turnheim 2009; Triguero, Moreno-Mondéjar, and Davia 2013). Criscuolo et al. (2014) assess the role of feed-in tariffs (FITs)
} 
The variable Research personnel $\left(R E S_{n t}\right)$ is intended to capture the human capital input in the knowledge production function and serve as a control for the National System of Innovation. The human capital input is approximated using data on the number of researchers per 1,000 employees in the domestic labor force. Human capital is considered an important input factor for economic growth (Romer, 1990). The Research personnel data was retrieved from the Main Science Technology Indicators published by the OECD (2008).

The count of granted wind energy patents $\left(K_{n t}\right)$ is used to see if there are inter-industry spillovers. The definition was derived from the World Intellectual Property Organization's International Patent Classification (IPC) Green Inventory, with the category of interest being F03D (Wind Motors). The F03D category covers the mechanisms for converting the energy of natural wind into useful mechanical power, as well as the transmission of such power to its point of use. ${ }^{19}$ The sources of spillovers - one of the questions of this study - were obtained by constructing three different Knowledge stocks, i.e., one national $\left(K_{n t}\right)$ the wind power sector, one public wind power $\mathrm{R} \& \mathrm{D}$ stock $\left(R \& D S_{n t}\right)$ and last a distance weight was applied to the international stocks $\left(D I K_{n t}\right) .{ }^{20}$ The patent-based knowledge stock was constructed using the socalled perpetual inventory method commonly employed for related purposes (e.g., Ek and Söderholm, 2010). Specifically, this knowledge stock is constructed as follows:

$$
K_{n t}=(1-\delta) K_{n(t-1)}+R_{n(t-x)}
$$

where $K_{n t}$ is the knowledge stock in country $n$ during time period $t$. Moreover, $\delta$ is the annual depreciation rate of the knowledge stock $(0 \leq \delta \leq 1), P C_{n t}$ represents the count of patents, and $x$ is the number of years (lag) it takes before new patents add to the knowledge stock (Hall and Scobie, 2006). The time lag is assumed to be three years. Following the approach adopted in

and renewable energy certificates (RECs) in creating incentives for cross-border investments in the solar and wind power sector, and conclude that FITs and RECs both encouraged such investments.

Robustness tests for the significance of such policies that could affect wind power patent propensity and development (e.g. The European Union Emissions Trading System, FITs and TRIPS (agreement on Trade-Related Aspects of Intellectual Property Rights 1994)) were controlled for (the results are displayed in Appendix Tables D1 to D4).

19 There are other classes in which patents relating to wind power are involved, such as those concerning the construction of wind towers. However, these are hard to distinguish from similar applications in other fields, so this study only addressed the main fields where the majority of wind power patents were filed.

${ }^{20}$ Furthermore, in many patent count models the knowledge stock of previously filed patents is included to account for a country’s absorptive capacity (Peters et al., 2012; Cohen and Levinthal, 1990). 
other studies (e.g., Griliches 1998; Corradini et al., 2014), a depreciation rate of 15\% was applied on the knowledge stocks. ${ }^{21}$

Each country's initial national knowledge stock $\left(K_{0}\right)$ is calculated as:

$$
K_{0}=\frac{R_{0}}{g+\delta}
$$

where $R_{0}$ is the number of wind power patent counts in the first year available (1977), and $g$ is the average geometric growth rate of granted wind power patents and R\&D for the first ten years in the respective country. The motivation for calculating an initial stock is that we in some cases can assume that there was wind power patent activity in the country prior to the starting year and hence to account for that activity. ${ }^{22}$

The other knowledge stocks tested have been designed in a corresponding way. The international wind power knowledge stock available for country $n$ is based on the accumulated granted wind power patent counts for all countries in the sample minus country $n$ 's own patents. This variable is used to test if the accumulation of patents in other countries has positive or negative effects on a country's level of related energy machinery patent production.

Previous research has revealed that knowledge spillovers have a tendency to materialize between geographically close regions (e.g., Maruseth and Verspagen 2002; Fischer et al., 2009), creating a diminishing probability of patent spillovers as geographical distance increases. The rate at which information flows without obstruction has improved in over the previous decades, possibly diminished the negative distance effect (Fischer et al., 2006; Johnson and Lybecker, 2012). The presence of country border effects is tested by applying distance weighting to the international knowledge stock (wind power $\left(D I K_{n t}\right)$.

Following Bode (2004) as well as by Costantini et al. (2013, 2014), the diminishing distance effect can be measured in terms of inverse distance where the intensity of cross-country knowledge spillovers is assumed to be subject to spatial transaction costs. The influence declines with distance, and to capture this effect a gravity approach was applied. The knowledge stocks are weighted as the inverse exponential relationship between countries. We have:

\footnotetext{
${ }^{21}$ Park and Park (2006) calculated the technological knowledge stock depreciation rate for 23 different industries and found that it was in the realm of 11.9-17.9\%. To check robustness tests were performed using 5 and 10 percent depreciation rates. These tests show that the results remained robust (see Appendix B, tables B1- 4).

${ }^{22}$ For some countries, the application of the average geometric growth rate did not matter as they had minimal $(0)$ patent activity observed in the initial years and, indeed, for some years after that.
} 


$$
D_{1} K s^{r}=\sum_{s=1, s \neq r}^{n}\left(K s^{r s} W_{r s}\right) \text { with } W_{r s}=D_{r s}^{-1}
$$

where $D_{1}$ is the distance weight, $K s^{r}$ is the stock that is weighted and $W_{r s}$ is the assigned weight. In equation (6), the shorter the distance between two countries, $s$ and $r(\forall s \neq r)$ the greater the weighting assigned to $s$ with respect to its influence on $r$. Therefore, the weighting assigned to each country $s, r$ is proportional to the inverse distance between $r$ and $s$ (Costantini et al., 2013). The distances between the various countries are determined, in line with Wolf (2000), by the location of the capital cities in the countries and the distance between them in kilometers as the crow flies.

Table 3 provides definitions and descriptive statistics for the variables that are used in the empirical investigation.

Table 3: Data definitions and descriptives

\begin{tabular}{|c|c|c|c|c|c|}
\hline Variable & Description & Mean & $\begin{array}{l}\text { Standard } \\
\text { deviation }\end{array}$ & Minimum & Maximum \\
\hline Patents granted & $\begin{array}{l}\text { Number (counts) of granted (based } \\
\text { on priority year) related energy } \\
\text { machinery patents over the time } \\
\text { period 1978-2008. }\end{array}$ & 59.22 & 59.79 & 4.00 & 223 \\
\hline$R \& D$ & $\begin{array}{l}\text { Public expenditures on wind power } \\
\text { R\&D in million USD ( } 2012 \text { prices } \\
\text { and assuming purchasing power } \\
\text { parity). }\end{array}$ & 9.88 & 10.32 & 0.143 & 61.55 \\
\hline$R \& D$ stock & $\begin{array}{l}\text { Stock of public expenditures on wind } \\
\text { power R\&D in million USD ( } 2012 \\
\text { prices and assuming purchasing } \\
\text { power parity). }\end{array}$ & 64.53 & 45.26 & 3.97 & 184.19 \\
\hline $\begin{array}{l}\text { Research } \\
\text { personnel }\end{array}$ & $\begin{array}{l}\text { Number of researchers per } 1,000 \\
\text { employees in the labor force in the } \\
\text { country. }\end{array}$ & 4.681 & 1.78 & 1.04 & 12.20 \\
\hline $\begin{array}{l}\text { National wind } \\
\text { stock }\end{array}$ & $\begin{array}{l}\text { Knowledge stock based on patents } \\
\text { granted (based on priority year) to } \\
\text { domestic inventors in the field of } \\
\text { wind power technology. }\end{array}$ & 8.133 & 17.95 & 0.00 & 111.81 \\
\hline $\begin{array}{l}\text { Distance- } \\
\text { weighted } \\
\text { international } \\
\text { stock }\end{array}$ & $\begin{array}{l}\text { International wind power knowledge } \\
\text { stock weighted via the inverse } \\
\text { distance method. }\end{array}$ & 0.578 & 0.63 & 0.02 & 3.03 \\
\hline
\end{tabular}

\section{Results}

Table 4 presents the empirical results from model specifications I-IV, i.e., the models addressing the presence of knowledge spillovers from wind power sector to the relating energy machinery sector. Model I and II covers the period 1978 - 2008 and model III - IV cover the 
period 1990 - 2008. The main coefficients of interest in Table 4 are those relating to the national wind stock and the $R \& D$ flow variable, respectively. Further tests will be displayed in table 5 where among other things the effect of an R\&D-stock is tested. A variable testing if there are any international knowledge spillovers are also included.

Models I - IV indicate that the variable $R \& D$-flow - the amount governments spend on wind power R\&D - is not statistically significant. Model I and II show that the coefficient representing the human capital variable, research personnel, was positive and statistically significant, in model III and IV the variable was not statistically significant. The variable national wind stock has a statistically significant negative coefficient in model I and III. In models II and IV, the inverse distance is applied to the international knowledge stocks. This procedure produced gave no statistically significant results.

Table 4: Parameter estimates for models I-IV

\begin{tabular}{|c|c|c|c|c|}
\hline Variable & Model I & Model II & Model III & Model IV \\
\hline$R \& D$-flow & $\begin{array}{l}0.001 \\
(0.21)\end{array}$ & $\begin{array}{l}0.019 \\
(0.21)\end{array}$ & $\begin{array}{l}0.004 \\
(0.43)\end{array}$ & $\begin{array}{l}0.002 \\
(0.25)\end{array}$ \\
\hline Research personnel & $\begin{array}{c}0.169 * * * \\
(2.81)\end{array}$ & $\begin{array}{c}0.164 * * * \\
(2.30)\end{array}$ & $\begin{array}{l}0.043 \\
(0.44)\end{array}$ & $\begin{array}{l}0.064 \\
(0.64)\end{array}$ \\
\hline National wind stock & $\begin{array}{c}-0.06 * * * \\
(-3.89)\end{array}$ & & $\begin{array}{c}-0.05 * * \\
(-2.11)\end{array}$ & \\
\hline $\begin{array}{l}\text { Distance-weighted } \\
\text { international wind } \\
\text { stock }\end{array}$ & & $\begin{array}{l}0.007 \\
(0.62)\end{array}$ & & $(0.09)$ \\
\hline Wald chi2 & 9192 & 9195 & 4216 & 4216 \\
\hline Observations & 232 & 232 & 136 & 136 \\
\hline Log-likelihood & -630.04 & -637.35 & -383.61 & -385.81 \\
\hline Prob $>=$ chibar 2 & 0.000 & 0.000 & 0.000 & 0.499 \\
\hline Time fixed effects & Yes & Yes & Yes & Yes \\
\hline Country Fixed effects & Yes & Yes & Yes & Yes \\
\hline
\end{tabular}

Notes: $* * *$ and $* * *$ indicate statistical significance at the $10 \%, 5 \%$ and $1 \%$ levels, respectively.

Table 5 displays the results from models V-VIII, i.e., addressing the knowledge spillovers emanating from related industries and how the stock of R\&D affects the development of related energy machinery. The set-up mirrors that of model I-IV, but instead focus on how the accumulation of public wind $R \& D$ has affected the patenting outcomes in the related energy machinery sector. Model V and VI covers the period 1978 - 2008 and model VII - VIII cover the period $1990-2008$.

The $R \& D$ (now a stock instead of flow variable) coefficients remain statistically non-significant in all models. The results for research personnel are consistent with those of the previous models, and the relevant coefficients were negative and statistically significant in model $\mathrm{V}$ and 
VII. In models VI and VIII, the variables National wind stock was found to have a statistically significant negative effects on related patent production. Moreover, the models testing the impacts of the distance-weighted international related stock indicated that also this variable was not statistically significantly related with domestic wind power production.

Table 5: Parameter estimates for models VI-X

\begin{tabular}{lcccc}
\hline \hline Variable & Model V & Model VI & Model VII & Model VIII \\
\hline \hline R\&D stock & -0.006 & -0.009 & 0.001 & 0.007 \\
& $(-0.29)$ & $(-0.41)$ & $(0.05)$ & $(0.24)$ \\
Research personnel & $0.131^{* *}$ & $0.156^{* *}$ & 0.05 & -0.74 \\
& $(2.12)$ & $(2.51)$ & $(0.57)$ & $(0.74)$ \\
National wind stock & $-0.06^{* * *}$ & & & \\
& $(-3.76)$ & & $-0.051^{* *}$ & \\
Distance-weighted & & 0.031 & $(-2.07)$ & \\
international related & & $(0.53)$ & & 0.014 \\
industries stock & 9190 & 9194 & 4216 & $(0.13)$ \\
\hline Wald chi2 & 232 & 232 & 136 & 4216 \\
Observations & -630.43 & -637.29 & -383.70 & -385.81 \\
Log-likelihood & 0.000 & 0.000 & 0.000 & 0.499 \\
Prob>=chibar2 & Yes & Yes & Yes & Yes \\
Time fixed effects & Yes & Yes & Yes & Yes \\
Country Fixed effects & & & & 136 \\
\hline \hline
\end{tabular}

Notes: $*, * *$ and $* * *$ indicate statistical significance at the $10 \%, 5 \%$ and $1 \%$ levels, respectively.

In Appendix B, robustness tests with regard to the depreciation rate of the knowledge stocks are presented where a depreciation rate of 5 and 10 percent was tested for both the time period 1978 - 2008 and 1990 - 2008. Furthermore, additional tests for the significance of such policies that could affect wind power patent propensity and development (e.g. The European Union Emissions Trading System, FITs and TRIPS ${ }^{23}$ ) were controlled for (the results are displayed in Appendix Tables D1 to D4). Rendering robust results.

\section{Discussion}

The overall findings of this analysis reject the notion that there are international knowledge spillovers across this particular technological domain are present and positive. In the analysis, of energy patents related to wind energy patents, the coefficients for the knowledge stock variables are negative and statistically significant across models. Moreover, coefficients on R\&D are not statistically significant; indicating no public spending crowding out, this was the case for both the accumulated stock and the flow of public R\&D spending.

\footnotetext{
${ }^{23}$ Agreement on Trade-Related Aspects of Intellectual Property Rights 1994
} 


\subsection{No international knowledge spillovers and national crowding out}

The variable national wind stock was statistically significant coefficient and negative in model I, III, V and VII. The statistically significant and negative result suggests that previous wind power research output in a country can have crowded out the accumulation of knowledge in related industries in the country and hence affect the domestic capacity for realizing future inventions in a negative way. In other words, the inventive capacity in the related fields were hindered by knowledge accumulation in the wind power field. Hence, there seems to be a tradeof between research fields, the extent of the trade of is not within the scope of this papers analysis however.

One possible explanation is that when resources are limited, and efforts are directed towards a particular industry some of the resources for other research are a scarce resource. However, as discussed in section 6.2, crowding out did not seem to be the case for R\&D founding. The result remains robust to different depreciation specifications (see appendix B and C).

The results from Section 5 (presented in table 4 and 5) indicates that advances in wind technologies did not create positive knowledge flows across technologies. Furthermore, the Distance-weighted international related industries stock was not significant indicating a lack of international knowledge spillovers between the technology fields. This result was initially somewhat surprising considering the previous literatures findings of international knowledge spillovers (e.g., Grafström, 2018). However, there are several reasons why there is a lack of knowledge spillovers between wind power and relating industries. Firstly, the variable "related industries" is an aggregate of several patent classes so there could be spillovers between some of the classes but not necessarily between all of them. Secondly, there is of course the possibility that there are no international knowledge spillovers in this particular setting, or that the distance weighting take away effects that are there. Previous studies (e.g., Johnstone and Haščič, 2010; Braun et al., 2011; Grafström and Lindman 2017; and Grafström, 2017) focused on knowledge spillovers in the wind power field and considered only effects on the totality of knowledge flows, the present contribution presents a new perspective on knowledge flows. Assessing intertechnology effects enable us to understand unintended consequences of policy decisions. ${ }^{24}$

\footnotetext{
${ }^{24}$ Because of knowledge spillovers and free-riding, the greatest benefits from renewable energy inventions are likely to be international rather than national (Mansfield 1977). International knowledge spillovers are perceived as important since if knowledge does not spill over, it is more reasonable for a national government to invest in the building up of a green industry domestically without having an incentive to be the second mover and free-ride on others' efforts (Fischer 2008; Jaffe, Newell, and Stavins 2005; Popp 2005). If, however, the knowledge from one country is found to spill over freely and easily to neighboring countries, then it could be more effective and efficient for cross-governmental entities like the European Union (EU) to devise and implement R\&D policies
} 
On a general level, there are implications for the literature on technological change that can be derived from the results presented. The results are relevant to incorporate into technology forecasting models who might undervalue technological change if the models fail to consider inter-technology flows. Technology forecasting models are central for scientific efforts such as integrated assessment models produced by the Intergovernmental Panel on Climate Change (Gillingham et al., 2008; IPCC, 2014). Considering the results of the present paper, especially with respect to the knowledge flows across technologies that are related to each other, these models might have to be adapted to reflect inter-technology learning effects.

\subsection{R\&D crowding out}

For public R\&D spending, no crowding out effects from public R\&D spending were found. Hence, as the level of government spending on wind power goes up the inventive output of related energy machinery is not affected. Beforehand we expected that there could be R\&D crowding out due to that in the sort run there are a limited capacity of researchers that can be allocated to different projects - making it plausible that the inventive activity contracts in some fields when the government change the relative prices of the cost of doing research.

Crowding out occurs when public R\&D funding drives out private funding partially or completely. Complete crowding out takes place when a public investment decreases the innovations in other fields partial crowding out occurs when total inventive output increases, but the inventive output is lower than it would have been. If data on privately financed $R \& D$ effort were available, then the extent of partial or complete crowding out effects could have been estimated however, the results given tells us that there are crowding out to some extent. The lack of R\&D crowding out finding does not suggest that the government are optimally allocating resources, the study does not contain a societal evaluation of the money spent and furthermore, the climate issue is rather pressing as noted previously. However, a dollar spent on wind power could be, but does not seem to be, a dollar that is not spent on another project.

Looking at the results in Model V-VIII, the $R \& D$ stock variable is not statistically significant. The result is not unanticipated. In the short run the $R \& D$ sending could have a crowding out effect (as seen in Model I -IV), but the accumulated level of past spending is probably less likely to affect the current day affairs. The positive statistically significant number (Model VI) could be due to that the accumulated spending is related to a countries general buildup of knowledge and hence affecting the invention climate. It can also be due to creation of a better absorptive capacity in the country. Having a generally well-developed domestic energy technology sector would help absorb knowledge flows both from national and international 
sources. This reasoning follows that of Aldieri and Cincera (2009) and Mancusi (2008), who show that a country's absorptive capacity benefits its ability to understand and exploit external knowledge.

Public policies play an important role in stimulating innovation in the renewable energy sector, since private firms have too weak incentives to make $R \& D$ investments in clean energy technologies (Jaffe et al., 2005). Another argument for why public policies need to combine the standard environmental policies (such as carbon taxes or permits) with R\&D support in clean technologies is that once the knowledge base in clean energy is large enough, firms will start innovating; rendering public policy intervention only temporary (Acemoglu et al., 2012, Aalbers et al., 2013). Hence, an improved knowledge of what kind of knowledge benefits existing technologies and what kind of knowledge has the potential to increase technological variety has important implications for policy makers that want to engage in R\&D spending.

\section{Concluding Remarks and Directions for Future Research}

The purpose of this paper is to provide a backward-looking analysis of how the accumulation of wind energy patents and public R\&D spending affected the domestic and neighboring country output of granted patents in the "related energy machinery field". The questions investigated are whether the development of wind power technology in one European country - measured through patent counts - affect the level of knowledge output in closely related fields the countries i.e., inter-technology spillovers. Furthermore, the presence of public R\&D crowding out was tested. These research questions were tested using a data set covering the eight major wind power nations in Western Europe during the period 1978-2008.

The empirical findings suggest that wind power knowledge development have a negative (crowding out) effect on related industries in the country and hence affect the domestic capacity for realizing future inventions in a negative way. The presence of knowledge flows between industry sectors has mostly been ignored in wind energy policy debates. If developers of wind energy technologies can learn from other sectors in the economy, it could well reduce the costs of innovation and increase the phase of technological development.

It was not a priori clear whether public R\&D support for knowledge production in renewable energy would, in actuality, enhance or reduce inter-sectoral knowledge but the accumulation of knowledge from wind power to related fields seem to have no effect. The analysis developed 
here shows that public R\&D funding appeared to have no crowding out effects. These findings have vital implications for the public strategy of science, technology and innovation policy.

Policy measures that encourage the development of a certain technology are likely to foster the development of a stable technological trajectory within a country, but policy measures targeted at developing a technology can reduce peripheral knowledge and contribute to less technological variety.

There are several ways to improve the analysis carried out here if newer data could be obtained, enough years have soon gone by to make a comprehensive analysis of the development in the modern era of wind power. An obvious way is by having observations on the same country for more periods, including before, during and after different major changes of the technology. This should allow a better control for unobserved country specific effects. It would also be helpful to have better variables, in special those related spending on the related industries. The analysis presented here is just a step for a better understanding of the effects of public R\&D subsidies and the effect of investments in a specific technology.

Outstanding questions include: whether government-sponsored energy technology research crowd out private initiatives? and are there ways of improving R\&D resource allocations? Given the significance of inter-industry knowledge flows found in these results, policy design for energy technology development would benefit from insight on these questions.

\section{References}

Aalbers, R., V. Shestalova, and V. Kocsis. 2013. "Innovation Policy for Directing Technical Change in the Power Sector." Energy Policy, 63, 1240-1250.

Acemoglu, D., P. Aghion, L. Bursztyn, and D. Hemous. 2012. "The Environment and Directed Technical Change." American Economic Review, 102(1), 131-166.

Adams, S. S. 2005. Information Sources in Patents. 1st ed. Munich: K. G. Saur Verlag.

Aldieri, L., and M. Cincera. 2009. "Geographic and Technological R\&D Spillovers within the Triad: Micro Evidence from US Patents.” The Journal of Technology Transfer, Vol. 34 (2): 196-211.

Allison P. D. and R. P. Waterman, 2002. "Fixed-Effects Negative Binomial Regression Models." Sociological Methodology 32:247- 265.

Antonelli, C. 1989. "A Failure-Inducement Model of Research and Development Expenditure: Italian Evidence from the Early 1980s." Journal of Economic Behavior \& Organization, 12(2), 159-180.

Antonelli, C. 2008. Localised Technological Change: Towards the Economics of Complexity. Routledge, London. 
Antonelli, C. and F. Quatraro. 2010. "The Effects of Biased Technological Change on Total Factor Productivity: Empirical Evidence from a Sample of OECD Countries." Journal of Technological Transfer, Vol. 35 (4): 361-383.

Antonelli, C., P. P., Patrucco, and F. Quatraro. 2011. "Productivity Growth and Pecuniary Knowledge Externalities: An Empirical Analysis of Agglomeration Economies in European Regions." Economic Geography, Vol. 87 (1): 23-50.

Arundel, A., and R. Kemp, 2009. "Measuring eco-innovation." UNU-MERIT Working Paper 2009-017, United Nations University, Maastricht Economic and Social Research and Training Centre on Innovation and Technology.

Archibugi, D., and Coco, A. 2005. "Measuring Technological Capabilities at the Country Level: A Survey and a Menu for Choice." Research Policy, 34(2), 175-194.

Arent, D. J., A. Wise, and R. Gelman. 2011. "The Status and Prospects of Renewable Energy for Combating Global Warming." Energy Economics 33 (4): 584-593.

Arrow, K. J. 1962. "The Economic Implications of Learning by Doing." The Review of Economic Studies, Vol. 29 (3): 155-173.

Battistelli, B. 2011. 2011 Filings in detail. http://blog.epo.org/the-epo/2011-filings-in-detail/.

Battke, B., Schmidt, T. S., Stollenwerk, S., \& Hoffmann, V. H. 2016. "Internal or External SpilloversWhich Kind of Knowledge is more likely to Flow within or Across Technologies." Research policy, 45(1), 27-41.

Baltagi, B. H. 2008. Econometric Analysis of Panel Data. 4th ed. Hoboken, NJ: John Wiley \& Sons.

Van den Bergh, J.C.J.M. 2008. "Optimal Diversity: Increasing Returns versus Recombinant Innovation." Journal of Economic Behavior \& Organization 68, 565-580.

Battistelli, B. 2011. 2011 Filings in Detail. http://blog.epo.org/the-epo/2011-filings-in-detail/.

Braun, F.G., J. Schmidt-Ehmcke, P., Zloczysti. 2011. "Innovative Activity in Wind and Solar Technology: Empirical Evidence on Knowledge Spillovers Using Patent Data." Discussion paper 993, German Institute for Economic Research, Germany.

Bode, E. 2004. "The Spatial Pattern of Localized R\&D Spillovers: An Empirical Investigation for Germany." Journal of Economic Geography, Vol. 4 (1): 43-64.

Bointner, R. 2014. "Innovation in the Energy Sector: Lessons Learnt from R\&D Expenditures and Patents in Selected IEA Countries." Energy Policy, 73: 733-747.

Boschma, R., and S. Iammarino. 2009. "Related Variety, Trade Linkages, and Regional Growth in Italy." Economic Geography, Vol. 85 (3): 289-311.

Busom, I. 2000. "An Empirical Evaluation of the Effects of R\&D Subsidies." Economics of Innovation and New Technology, 9(2), 111-148.

Cohen, W. M., and Levinthal, D. A. 1989. "Innovation and Learning: the two Faces of R\&D." The Economic Journal, Vol. 99 (397): 569-596.

Cohen, W. M., and D. A. Levinthal. 1990. "Absorptive Capacity: A New Perspective on Learning and Innovation.” Administrative Science Quarterly, Vol. 35: 128-152.

Cohen, W. M., R. R. Nelson, and J. P. Walsh. 2000. "Protecting their Intellectual Assets: Appropriability Conditions and Why US Manufacturing Firms Patent (or Not)." National Bureau of Economic Research Working Paper Series No. 7552. Cambridge, MA: NBER.

Corradini, M., V. Costantini, S. Mancinelli, and M. Mazzanti. 2014. "Unveiling the Dynamic Relation between R\&D and Emission Abatement: National and Sectoral Innovation Perspectives from the EU.” Ecological Economics, Vol. 102: 48-59. 
Corradini, M., V. Costantini, S. Mancinelli, and M. Mazzanti. 2015. "Interacting Innovation Investments and Environmental Performances: A Dynamic Impure Public Good Model." Environmental Economics and Policy Studies, Vol. 17 (1): 109-129.

Costantini, V., and F. Crespi. 2008a. "Environmental Regulation and the Export Dynamics of Energy Technologies." Ecological Economics, Vol. 66 (2): 447-460.

Costantini V, and F. Crespi. 2008b "Environmental Institutions and the Trade of Energy Technologies in Europe." International Journal of Global Environmental Issues 8:445-460

Costantini, V., M. Mazzanti, and A. Montini. 2013. "Environmental Performance, Innovation and Spillovers: Evidence from a Regional NAMEA.” Ecological Economics, Vol. 98: 101-114.

Costantini, V., F. Crespi, and Y. Curci. 2015. “A Keyword Selection Method for Mapping Technological Knowledge in Specific Sectors Through Patent Data: The Case of Biofuels Sector." Economics of Innovation and New Technology, Vol. 24 (4): 282-308.

Criscuolo, C., N. Johnstone, C. Menon, and V. Shestalova. 2014. "Renewable Energy Policies and Cross-Border Investment: Evidence from Mergers and Acquisitions in Solar and Wind Energy." OECD Science, Technology and Industry Working Papers 2014/3, OECD.

Dechezleprêtre, A., R. Martin, and M. Mohnen. 2013. "Knowledge Spillovers from Clean and Dirty Technologies: A Patent Citation Analysis." Centre for Climate Change Economics and Policy Working Paper No. 151 and Grantham Research Institute on Climate Change and the Environment Working Paper No. 135. Leeds/London: University of Leeds/London School of Economics.

Dechezleprêtre, A., and M., Glachant. 2014. "Does Foreign Environmental Policy Influence Domestic Innovation? Evidence from the Wind Industry." Environmental and Resource Economics, Vol. 58 (3): 391-413.

Dekker, T., H. Vollebergh, F. de Vries, and C. Withagen. 2012. "Inciting Protocols." Journal of Environmental Economics and Management, 64, 45-67.

De Vries, F. P., and C. Withagen. 2005. "Innovation and Environmental Stringency: The Case of Sulfur Dioxide Abatement." Center Discussion Paper Series No. 2005-18, Tilburg University, Tilburg.

Dietz, S., and Maddison, D. S. 2009. "New Frontiers in the Economics of Climate Change." Environmental Research Economics, Vol. (43): 295-306.

Dosi, G. 1982. "Technological Paradigms and Technological Trajectories: A Suggested Interpretation of the Determinants and Directions of Technical Change." Research Policy 11, 147-162.

Ek, K., and P. Söderholm. 2010. "Technology Learning in the Presence of Public R\&D: The Case of European Wind Power.” Ecological Economics, Vol. 69 (12): 2356-2362.

Eaton, J., and S. Kortum. 1999. "International Technology Diffusion: Theory and Measurement." International Economic Review, Vol. 40 (3): 537-570.

Fischer, C. and R., Newell. 2004. "Environmental and Technology Policies for Climate Change and Renewable Energy. Resources for the Future, Discussion Paper $04-05$.

Fischer, C. 2008. "Emissions pricing, spillovers, and public investment in Environmentally Friendly Technologies." Energy Economics, Vol. 30 (2): 487-502.

Fischer, M. M. 2013. "The Geography of Knowledge Spillovers in Europe." In Innovation for Development, edited by T. de Noronha Vaz, 97-110. 1st ed. Faro: Research Center for Spatial and Organizational Dynamics, University of Algarve.

Fischer, M. M., T. Scherngell, and E. Jansenberger. 2006. "The Geography of Knowledge Spillovers between High-technology Firms in Europe: Evidence from a Spatial Interaction Modeling Perspective." Geographical Analysis, Vol. 38 (3): 288-309. 
Fischer, M. M., T. Scherngell, and E. Jansenberger. 2009. "Geographic Localization of Knowledge Spillovers: Evidence from High-tech Patent Citations in Europe." The Annals of Regional Science, Vol. 43 (4): 839-858.

Furman, J. L., Porter, M. E., and Stern, S. 2002. "The Determinants of National Innovative Capacity." Research Policy, 31(6):899-933.

Garrone, P., and L. Grilli. 2010. "Is There A Relationship Between Public Expenditures in Energy R\&D and Carbon Emissions Per GDP? An Empirical Investigation." Energy Policy, 38(10): 5600-5613.

Gillingham, K., Newell, R.G., and W. Pizer. 2008. "Modeling Endogenous Technological Change for Climate Policy Analysis.” Energy Economics 30, 2734-2753.

Grafström, J., and Å. Lindman. 2017. "Invention, Innovation and Diffusion in the European Wind Power Sector." Technological Forecasting and Social Change, 114: 179-191.

Grafström, J. 2018. "International Knowledge Spillovers in the Wind Power Industry: Evidence from the European Union." Economics of Innovation and New Technology, 1-20.

Greene, W. H. 2012. Econometric Analysis. 7th ed. Essex: Pearson Education.

Greene W. H. 2007. "Fixed and random effects models for count data." Working paper Department of Economics, Stern School of Business, New York University, New York.

Griliches, Z. 1979. "Issues in Assessing the Contribution of Research and Development to Productivity Growth.” The Bell Journal of Economics, Vol. 10 (1): 92-116.

Griliches, Z. 1980. "Returns to R\&D Expenditures in the Private Sector.” In: Kendrick, K., Vaccara, B. (Eds.), New Developments in Productivity Measurement. Chicago University Press, Chicago, IL.

Griliches, Z. 1987. "R\&D and Productivity: Measurement Issues and Econometric Results." Science, Vol. 237 (4810): 31-35.

Griliches, Z. 1992. “The Search for R\&D Spillovers.” Scandinavian Journal of Economics, Vol. 28: 1661-1707.

Griliches, Z. 1998. "Patent Statistics as Economic Indicators: A Survey", In R\&D and Productivity: The Econometric Evidence, edited by Z. Griliches, 287-343. Chicago: University of Chicago Press.

Guellec, D. and B. van Pottelsberghe. 1997. "Does Government Support Stimulate Private R\&D." OECD Economic Studies, 29, 95-122.

Guellec, D. and B. van Pottelsberghe. 2003. "The Impact of Public R\&D Expenditures on Business R\&D." Economics of Innovation and New technologies 12(3), 225-244.

Grossman, G., and Helpman, E. 1991. Innovation and growth in the global economy. Cambidge, MA: MIT Press.

Hall, B. H. 2002. "The Financing of Research and Development." Oxford Review of Economic Policy $18(1), 35-51$.

Hall, B. H., and R. H. Ziedonis. 2001. "The Patent Paradox Revisited: An Empirical Study of Patenting in the US Semiconductor Industry, 1979-1995." The RAND Journal of Economics, Vol. 32 (1): $101-128$.

Hall, J., and G. Scobie. 2006. "The Role of R\&D in Productivity Growth: The Case of Agriculture in New Zealand: 1927 to 2001.” Wellington: New Zealand Treasury.

Hausman, J., B. H. Hall, and Z. Griliches. 1984. "Econometric Models for Count Data with an Application to the Patents-R\&D Relationship." Econometrica, Vol. 52 (4): 909-938.

Hussler, C. 2004. "Culture and Knowledge Spillovers in Europe: New Perspectives for Innovation and Convergence Policies?” Economics of Innovation and New Technology, Vol. 13 (6): 523-541.

Ibenholt, K. 2002. "Explaining Learning Curves for Wind Power.” Energy Policy, Vol. 30 (13): 11811189. 
International Energy Agency (IEA) 2012. Energy Technology RD\&D Budgets: Beyond 2020 Documentation, 2012 Edition, Paris 2012.

Intergovernmental Panel on Climate Change (IPCC). 2007. Climate change 2007: The physical science basis, contribution of working group $i$ to the fourth assessment, report of the Inter- governmental Panel on Climate Change, Geneva.

Intergovernmental Panel on Climate Change (IPCC). 2013. Climate change 2013: The physical science basis, contribution of working group $i$ to the fifth assessment, report of the Inter-governmental Panel on Climate Change, Geneva.

IPCC. 2014. Climate Change 2014 - Mitigation of Climate Change. Intergovernmental Panel on Climate Change (IPCC).

Jaffe, A. B. 2002. "Building Programme Evaluation into Design of Public Research-SupportProgrammes." Oxford Review of Economic Policy 18(1), 22-34.

Jaffe AB, Newell RG, and R. N. Stavins. 2004. Technology policy for energy and the environment. In: Jaffe AB, Lerner J, Stern S (eds) Innovation policy and the economy, vol 4. MIT Press, Cambridge, MA, pp $35-68$.

Jaffe, A. B., R. G. Newell, and R. N. Stavins. 2005. "A Tale of Two Market Failures: Technology and Environmental Policy.” Ecological Economics, Vol. 54 (2): 164-174.

Joutz, F. L., and M. Y. Abdih. 2005. "Relating the Knowledge Production Function to Total Factor Productivity: An Endogenous Growth Puzzle" Working paper (No. 5-74). International Monetary Fund (IMF). Middle East and Central Asia Department.

Johnstone, N. and I. Haščič. 2010. "Directing Technological Change while Reducing the Risk of (not) Picking Winners: The Case of Renewable Energy." OECD working paper.

Jungmittag, A. 2006. "Innovation dynamics in the EU: Convergence or Divergence? A Cross-country Panel Data Analysis.” Empirical Economics, 31(2), 313-331.

Johnson, D., and K. M. Lybecker. 2012. "Does Distance Matter Less Now? The Changing Role of Geography in Biotechnology Innovation." Review of Industrial Organization, Vol. 40 (1): 21-35.

Keefe, P. 2010. "Is the Focus and Provision of the IPC Suitable for Analysis of Environmentally Sound Technology?" Unpublished paper presented at the joint European Patent Office Branch \& UK Intellectual Property Office Conference entitled "Patent Statistics for Decision Makers", held at the European Patent Office Branch \& UK Intellectual Property Office, London.

Klaassen, G., A. Miketa, K. Larsen, and T. Sundqvist. 2005. "The Impact of R\&D on Innovation for Wind Energy in Denmark, Germany and the United Kingdom." Ecological Economics, Vol. 54 (2-3): 227-240.

Krammer, S. 2009. "Drivers of National Innovation in Transition: Evidence from a Panel of Eastern European Countries." Research Policy, Vol. 38 (5): 845-860.

Lazear, E. 2004. "Balanced Skills and Entrepreneurship." American Economic Review 94, 208-211.

Lettl, C., Rost, K., and von Wartburg, I. 2009. "Why Are Some Independent Inventors "Heroes" And Others "Hobbyists"? The Moderating Role of Technological Diversity and Specialization." Research Policy 38, 243-254.

Link, A. N. 1982. "Productivity Growth, Environmental Regulations and the Composition of R\&D." Bell Journal of Economics 13 (2), 548-554.

Lybbert, T. J., and Zolas, N. J. (2014). "Getting Patents and Economic Data to Speak to each other: An 'Algorithmic Links with Probabilities' Approach for Joint Analyses of Patenting and Economic Activity." Research Policy, 43(3), 530-542.

Mansfield, E. 1977. The Production and Application of New Industrial Technology. Norton. 
Mancusi, M. L. 2008. "International Spillovers and Absorptive Capacity: A Cross-country Cross-sector Analysis Based on Patents and Citations." Journal of International Economics, Vol. 76 (2): 155165.

Maruseth, P. B., and B. Verspagen. 2002. "Knowledge Spillovers in Europe: A Patent Citations Analysis." Scandinavian Journal of Economics, Vol. 104 (4): 531-545.

Nelson, R. 1959. "The Simple Economics of Basic Scientific Research.” Journal of Political Economy. 67, 297-306.

Nemet, G. F., and Kammen, D. M. 2007. "U.S. Energy Research and Development: Declining Investment, Increasing Need, And the Feasibility of Expansion." Energy Policy 35, 746-755.

Nemet, G. F. 2012. “Inter-Technology Knowledge Spillovers for Energy Technologies.” Energy Economics 34, 1259-1270.

Nemet, G. F., and E. Johnson. 2012. "Do Important Inventions Benefit from Knowledge Originating in Other Technological Domains?" Research Policy 41, 190-200.

Nicolli, F., N. Johnstone, and P. Söderholm. 2012. "Resolving Failures in Recycling Markets: The Role of Technological Innovation.” Environmental Economics and Policy Studies, Vol. 14 (3): 261288.

Noailly, J., and V. Shestalova. 2013. "Knowledge Spillovers from Renewable Energy Technologies Lessons from Patent Citations." CPB Discussion Paper.

Nordhaus, W. D. 2002. Modeling Induced Innovation in Climate- Change Policy. In: Grqbler, A., Nakicenovic, N., Nordhaus, W. D. (Eds.), Technological Change and the Environment. Resources for the Future, Washington, DC, pp. 182-209.

OECD (Organisation for Economic Co-operation and Development). 2008. Main Science and Technology Indicators. Paris: OECD.

OECD 2015. Measuring Environmental Innovation Using Patent Data. OECD Environment Working Papers, No. 89.

Pakes, A. 1985. "On Patents, R\&D, and the Stock Market Rate of Return." Journal of Political Economy, Vol. 93 (2): 390-409.

Pakes, A., and Z. Griliches. 1980. "Patents and R\&D at the Firm Level: A First Report." Economics Letters, Vol. 5 (4): 377-381.

Park, G., and Y. Park. 2003. "An Empirical Analysis of the Inter-industrial Spillover Effect of Information and Communications Technology on Cost and Labor - The Case of Korea." Journal of Scientific and Industrial Research, Vol. 62 (3): 157-167.

Park, G., and Y. Park. 2006. "On the Measurement of Patent Stock as Knowledge Indicators." Technological Forecasting and Social Change, Vol. 73 (7): 793-812.

Peters, M., Schneider, M., Griesshaber, T., and Hoffmann, V. H. 2012. "The Impact of TechnologyPush and Demand-Pull Policies on Technical Change - Does the Locus of Policies Matter?" Research Policy, Vol. 41 (8): 1296-1308.

Popp, D. 2002. "Induced Innovation and Energy Prices.” American Economic Review, 92, 160-180.

Popp, D. 2005. "Lessons from Patents: Using Patents to Measure Technological Change in Environmental Models." Ecological Economics, Vol. 54 (2): 209-226.

Popp, D. 2006. "R\&D Subsidies and Climate Policy: Is There A "Free Lunch"?" Climatic Change, 77 (3-4), 311-341.

Popp, D., and Newell, R. 2012. "Where Does Energy R\&D Come From? Examining Crowding Out from Energy R\&D.” Energy Economics, 34, 980-991. 
Roediger-Schluga, T. 2003. "Some Micro-Evidence on the "Porter Hypothesis" From Austrian VOC Emission Standards." Growth and Change 34 (3), 359-379.

Romer, P. M. 1990. "Endogenous Technological Change.” Journal of Political Economy, Vol. 98 (5, Part 2): 71-102.

Rübbelke, D., and P. Weiss. 2011. "Environmental Regulations, Market Structure and Technological Progress in Renewable Energy Technology: A Panel Data Study on Wind Turbines." Fondazione Eni Enrico Mattei Working Paper Series. Milan: Fondazione Eni Enrico Mattei.

Santos Silva, J. M. C. and Tenreyro, S. (2006). "The Log of Gravity." The Review of Economics and Statistics, 88(4), 641-658. 7, 9, 21.

Schankerman, M., and A. Pakes. 1987. "Estimates of the Value of Patent Rights in European Countries During the Post-1950 Period." National Bureau of Economic Research Working Paper No. 1650 (Also Reprint No. r0861). Cambridge, MA: NBER.

Scherer, F. M., and D. Harhoff. 2000. "Technology Policy for a World of Skew-distributed Outcomes." Research Policy, Vol. 29 (4): 559-566.

Schmoch, U., Laville, F., Patel, P., and R. Frietsch. 2003. "Linking technology areas to industrial sectors." Final Report to the European Commission. DG Research, Brussels.

Schneider, S. H. and L. H Goulder. 1997. Achieving Low-cost Emissions Targets. Nature 389:13 - 14

Schumpeter, J. A., 1934. The Fundamental Phenomenon of Economic Development. Harvard University Press, Cambridge, MA.

Schoenmakers, W., and G. Duysters. 2010. "The Technological Origins of Radical Inventions." Research Policy, 39, 1051-1059.

Sorensen, T. 2008. "Counselor: A Life at the Edge of History." New York: HarperCollins Publishers. Print. Page 227.

Stern, N. 2007. The Economics of Climate Change: The Stern Review. Cambridge University Press, New York.

Sterner, T., and B. Turnheim. 2009. "Innovation and Diffusion of Environmental Technology: Industrial NOx Abatement in Sweden under Refunded Emission Payments." Ecological Economics, 68 (12): 2996-3006.

Suganthi, L., and A. Samuel. 2012. "Energy Models for Demand Forecasting: A Review." Renewable and Sustainable Energy Reviews. Vol. 16 (2): 1223-1240.

Söderholm, P., Ek, K., and Pettersson, M. 2007. "Wind Power Development in Sweden: Global Policies and Local Obstacles." Renewable and Sustainable Energy Reviews, Vol. 11 (3): 365-400.

Söderholm, P., and T. Sundqvist. 2007. "Empirical Challenges in the Use of Learning Curves for Assessing the Economic Prospects of Renewable Energy Technologies." Renewable Energy, Vol. 32 (15): 2559-2578.

Söderholm, P., and G. Klaassen. 2007. "Wind Power in Europe: A Simultaneous Innovation-Diffusion Model." Environmental and Resource Economics, Vol. 36 (2): 163-190.

Trajtenberg, M. 2001. "Innovation in Israel 1968-1997: A Comparative Analysis Using Patent Data." Research Policy, Vol. 30 (3): 363-389.

Triguero, A., L. Moreno-Mondéjar, and M. A. Davia. 2013. "Drivers of Different Types of EcoInnovation in European SMEs." Ecological Economics 92: 25-33.

Yang, C.-J., and M. Oppenheimer. 2007. "A "Manhattan Project” for Climate Change?" Climatic Change 80 (3-4), 199-204.

Wolf, H. C. 2000. "Intranational Home Bias in Trade." Review of Economics and Statistics, Vol. 82 (4): $555-563$ 
Vitae

Jonas Grafström is a researcher at the Ratio institute and a guest associate professor at Lulea University of Technology. He holds MS from University of Toledo, Ohio and a Ph.D in Economics from Luleå University of Technology (LTU). His main research interest is within the fields of renewable energy and technological change.

\section{Appendix A}

Table A1: Correlation matrix

\begin{tabular}{|c|c|c|c|c|c|c|}
\hline & $\begin{array}{l}\text { Patents } \\
\text { granted }\end{array}$ & $\begin{array}{l}\text { National } \\
\text { wind stock }\end{array}$ & $R \& D$ & $R \& D$ stock & $\begin{array}{l}\text { Research } \\
\text { personnel }\end{array}$ & $\begin{array}{c}\text { Distance- } \\
\text { weighted } \\
\text { international } \\
\text { stock }\end{array}$ \\
\hline Patents granted & 1.00 & & & & & \\
\hline National wind stock & 0.27 & 1.00 & & & & \\
\hline$R \& D$ & -0.11 & 0.36 & 1.00 & & & \\
\hline$R \& D$ stock & -0.12 & 0.28 & 0.68 & 1.00 & & \\
\hline Research personnel & 0.31 & 0.63 & 0.27 & -0.10 & 1.00 & \\
\hline $\begin{array}{l}\text { Distance-weighted } \\
\text { international stock }\end{array}$ & 0.76 & 0.66 & 0.17 & 0.02 & 0.67 & 1.00 \\
\hline
\end{tabular}




\section{Appendix B}

Table B1: Parameter estimates for models I-IV with a 10\% depreciation rate to the wind power knowledge stocks and distance weighted stock. Model Ia and IIa covers the period 1978 - 2008 and model IIIa - IVa cover the period 1990 - 2008.

\begin{tabular}{lcccc}
\hline \hline Variable & Model Ia & Model IIa & Model IIIa & Model IVa \\
\hline \hline Research personnel & $0.14^{* * *}$ & $2.16^{* *}$ & 0.08 & 0.042 \\
& $(2.41)$ & $(2.16)$ & $(0.52)$ & $(0.37)$ \\
$R \& D$ - flow & $0.01^{*}$ & 0.002 & 0.011 & 0.03 \\
& $(9.37)$ & $(0.30)$ & $(1.00)$ & $(0.37)$ \\
National wind stock 10 & $-0.07^{* * *}$ & & $-0.05^{* *}$ & \\
& $(-3.46)$ & & $(-2.01)$ & \\
Distance-weighted & & & & -1.47 \\
international wind & & -0.305 & & $(-0.40)$ \\
stock & & $(-0.18)$ & & 4216 \\
\hline Wald chi2 & 9138 & 9195 & 4217 & 136 \\
Observations & 232 & 232 & 136 & -385.73 \\
Log-likelihood & -628.96 & -637.53 & -383.80 & 0.499 \\
Prob>=chibar2 & 0.000 & 0.000 & 0.000 & Yes \\
Time fixed effects & Yes & Yes & Yes & Yes \\
Country Fixed effects & Yes & Yes & Yes & \\
\hline \hline
\end{tabular}

Notes: $*, * *$ and $* * *$ indicate statistical significance at the $10 \%, 5 \%$ and $1 \%$ levels, respectively.

Table B2: Parameter estimates for models V-VIII with a 5\% depreciation rate to the wind power knowledge stocks and distance weighted stock. Model Vb and VIb covers the period 1978 - 2008 and model VIIb - VIIIb cover the period 1990 - 2008.

\begin{tabular}{lcccc}
\hline \hline Variable & Model Vb & Model VIb & Model VIIb & Model VIIIb \\
\hline \hline R\&D - flow & $0.176^{*}$ & 0.002 & 0.011 & 0.003 \\
& $(1.75)$ & $(0.29)$ & $(1.02)$ & $(0.30)$ \\
Research personnel & $0.134^{* *}$ & $0.164^{* *}$ & 0.049 & 0.05 \\
& $(2.31)$ & $(2.17)$ & $(0.49)$ & $(0.43)$ \\
National related stock 5 & $-0.09 * * *$ & & $-0.078^{* *}$ & \\
& $(-3.73)$ & & $(2.05)$ & \\
Distance-weighted & & & & \\
international related & & -0.194 & & -0.908 \\
industries stock & & $(-0.12)$ & & $(-0.25)$ \\
\hline Wald chi2 & 9137 & 9195 & 4216 & 4216 \\
Observations & 232 & 232 & 136 & 136 \\
Log-likelihood & -628.42 & -637.54 & -383.73 & -385.78 \\
Prob>=chibar2 & 0.000 & 0.000 & 0.000 & 0.499 \\
Time fixed effects & Yes & Yes & Yes & Yes \\
Country Fixed effects & Yes & Yes & Yes & Yes \\
\hline \hline
\end{tabular}

Notes: $* * *$ and $* * *$ indicate statistical significance at the $10 \%, 5 \%$ and $1 \%$ levels, respectively. 
Table B3: Parameter estimates for models I-IV with a 10\% depreciation rate to the wind power knowledge stocks and distance weighted stock. Model Ic and IIc covers the period 1978 - 2008 and model IIIc - IVc cover the period $1990-2008$.

\begin{tabular}{lcccc}
\hline \hline Variable & Model Ic & Model IIc & Model IIIc & Model IV \\
\hline \hline$R \& D$-stock & 0.002 & 0.000 & 0.024 & 0.005 \\
& $(0.09)$ & $(0.04)$ & $(0.88)$ & $(0.13)$ \\
Research personnel & $1.63^{* *}$ & $0.16^{* *}$ & 0.08 & 0.05 \\
& $(2.49)$ & $(1.97)$ & $(0.56)$ & $(0.48)$ \\
National wind stock 10 & $-0.062^{* * *}$ & & & \\
& $(-3.05)$ & & $-0.056 *$ & \\
Distance-weighted & & -0.26 & $(-1.85)$ & -1.30 \\
international wind & & $(-0.15)$ & & $(-0.35)$ \\
stock & & 9194 & 4217 & 4216 \\
\hline Wald chi2 & 9190 & 232 & 136 & 136 \\
Observations & 232 & -637.57 & -384.14 & -385.77 \\
Log-likelihood & -630.43 & 0.000 & 0.000 & 0.499 \\
Prob>=chibar2 & 0.000 & Yes & Yes & Yes \\
Time fixed effects & Yes & Yes & Yes & Yes \\
Country Fixed effects & Yes & & & \\
\hline \hline Notes: $* * *$ and $* * *$ indicate statistical significance at the 10\%, 5\% and 1\% levels, respectively.
\end{tabular}

Table B4: Parameter estimates for models I-IV with a 5\% depreciation rate to the wind power knowledge stocks and distance weighted stock. Model Vd and VId covers the period 1978 2008 and model VIId - VIIId cover the period 1990 - 2008.

\begin{tabular}{lcccc}
\hline \hline Variable & Model Vd & Model VId & Model VIId & Model VIIId \\
\hline \hline R\&D - stock & $0.017^{*}$ & 0.004 & 0.041 & 0.007 \\
& $(1.75)$ & $(0.13)$ & $(-.90)$ & $(0.12)$ \\
Research personnel & $0.16^{* *}$ & $0.174^{* *}$ & 0.04 & 0.063 \\
& $(2.17)$ & $(1.98)$ & $(0.64)$ & $(0.55)$ \\
National related stock 5 & $-0.079^{* * *}$ & & & \\
& $(-3.30)$ & & $-0.069 *$ & \\
Distance-weighted & & -0.120 & $(1.90)$ & \\
international related & & $(-0.08)$ & & -0.703 \\
industries stock & & 9135 & 4216 & $(-0.19)$ \\
\hline Wald chi2 & 9195 & 232 & 136 & 4216 \\
Observations & 232 & -629.55 & -384.04 & 136 \\
Log-likelihood & -637.54 & 0.000 & 0.000 & -385.81 \\
Prob>chibar2 & 0.000 & Yes & Yes & 0.499 \\
Time fixed effects & Yes & Yes & Yes & Yes \\
Country Fixed effects & Yes & & & \\
\hline \hline
\end{tabular}

Notes: $*, * *$ and $* * *$ indicate statistical significance at the $10 \%, 5 \%$ and $1 \%$ levels, respectively. 


\section{Appendix C}

Table C1: Parameter estimates for models I-II with test for significant policy's affecting wind power with a $15 \%$ depreciation rate to the wind power knowledge stocks and distance weighted stock. Covers the period $1978-2008$. R\&D flow.

\begin{tabular}{|c|c|c|c|c|c|c|}
\hline VARIABLES & 1 & 2 & 3 & 4 & 5 & 6 \\
\hline$R \& D$-flow & $\begin{array}{c}0.00871 \\
(0.00934)\end{array}$ & $\begin{array}{c}0.00197 \\
(0.00929)\end{array}$ & $\begin{array}{c}0.00871 \\
(0.00934)\end{array}$ & $\begin{array}{c}0.00197 \\
(0.00929)\end{array}$ & $\begin{array}{c}0.00877 \\
(0.00934)\end{array}$ & $\begin{array}{c}0.00299 \\
(0.00930)\end{array}$ \\
\hline $\begin{array}{l}\text { Research } \\
\text { personnel }\end{array}$ & $0.128 * *$ & $0.165^{* * *}$ & $0.128^{* *}$ & $0.165 * * *$ & $0.131 * *$ & $0.168 * * *$ \\
\hline $\begin{array}{l}\text { National wind } \\
\text { stock }\end{array}$ & $\begin{array}{c}(0.0585) \\
-0.0660 * * *\end{array}$ & $(0.0585)$ & $\begin{array}{c}(0.0585) \\
-0.0660 * * *\end{array}$ & $(0.0585)$ & $\begin{array}{c}(0.0587) \\
-0.0639 * * *\end{array}$ & $(0.0585)$ \\
\hline TRIPS & $\begin{array}{c}(0.0170) \\
2.522 * * * \\
(0.113)\end{array}$ & $\begin{array}{c}2.276 * * * \\
(0.177)\end{array}$ & $(0.0170)$ & & $(0.0177)$ & \\
\hline $\begin{array}{l}\text { Distance- } \\
\text { weighted } \\
\text { international } \\
\text { wind stock }\end{array}$ & & 0.0358 & & 0.0358 & & 0.0301 \\
\hline EUETS & & $(0.0581)$ & $\begin{array}{c}2.522 * * * \\
(0.113)\end{array}$ & $\begin{array}{c}(0.0581) \\
2.276^{* * * *} \\
(0.177)\end{array}$ & & $(0.0582)$ \\
\hline FeedIn & & & & & $\begin{array}{c}-0.00132 \\
(0.00331) \\
\end{array}$ & $\begin{array}{r}-0.00465 \\
(0.00320) \\
\end{array}$ \\
\hline Wald chi2 & 9195 & 9192 & 9195 & 9195 & 99192 & 9195 \\
\hline Observations & 232 & 232 & 232 & 232 & 232 & 232 \\
\hline Log-likelihood & -630.04 & -629.55 & -637.35 & -630.04 & -629.96 & -636.28 \\
\hline Prob $>=$ chibar 2 & 0.000 & 0.000 & 0.000 & 0.000 & 0.000 & 0.000 \\
\hline $\begin{array}{l}\text { Time fixed } \\
\text { effects }\end{array}$ & Yes & Yes & Yes & Yes & Yes & Yes \\
\hline $\begin{array}{l}\text { Country Fixed } \\
\text { effects }\end{array}$ & Yes & Yes & Yes & Yes & Yes & Yes \\
\hline
\end{tabular}

Table C2: Parameter estimates for models V-VI with test for significant policy's affecting wind power with a $15 \%$ depreciation rate to the wind power knowledge stocks and distance weighted stock. Covers the period $1978-2008$. R\&D stock.

\begin{tabular}{lcccccc}
\hline \hline VARIABLES & 1 & 2 & 3 & 4 & 5 & 6 \\
\hline \hline$R \& D$-stock & -0.00675 & -0.00970 & -0.00675 & -0.00970 & -0.00597 & -0.00639 \\
& $(0.0230)$ & $(0.0236)$ & $(0.0230)$ & $(0.0236)$ & $(0.0231)$ & $(0.0237)$ \\
Research & $0.132^{* *}$ & $0.157^{* *}$ & $0.132^{* * *}$ & $0.157^{* *}$ & $0.135^{* *}$ & $0.165^{* * *}$ \\
personnel & & & & & & \\
& $(0.0622)$ & $(0.0624)$ & $(0.0622)$ & $(0.0624)$ & $(0.0628)$ & $(0.0626)$ \\
$\begin{array}{l}\text { National } \\
\text { stock }\end{array}$ & $-0.0630^{* * *}$ & & $-0.0630^{* * *}$ & & $-0.0611^{* * *}$ & \\
TRIPS & $(0.0168)$ & & $(0.0168)$ & & $(0.0175)$ & \\
& $2.533^{* * *}$ & $2.310^{* * *}$ & & & & \\
$\begin{array}{l}\text { Distance- } \\
\text { weighted }\end{array}$ & $(0.123)$ & $(0.197)$ & & & & 0.0287
\end{tabular}




\begin{tabular}{|c|c|c|c|c|c|c|}
\hline & & $(0.0595)$ & & $(0.0595)$ & & $(0.0594)$ \\
\hline EUETS & & & $\begin{array}{c}2.533 * * * \\
(0.123)\end{array}$ & & & \\
\hline FeedIn & & & & & $\begin{array}{c}-0.00119 \\
(0.00333) \\
\end{array}$ & $\begin{array}{l}-0.00449 \\
(0.00321) \\
\end{array}$ \\
\hline Wald chi2 & 9190 & 9194 & 9190 & 9194 & 9190 & 9194 \\
\hline Observations & 232 & 232 & 232 & 232 & 232 & 232 \\
\hline Log-likelihood & -630.43 & -637.29 & -630.43 & -637.29 & -630.96 & -636.28 \\
\hline Prob $>=$ chibar 2 & 0.000 & 0.000 & 0.000 & 0.000 & 0.000 & 0.000 \\
\hline $\begin{array}{l}\text { Time fixed } \\
\text { effects }\end{array}$ & Yes & Yes & Yes & Yes & Yes & Yes \\
\hline $\begin{array}{l}\text { Country Fixed } \\
\text { effects }\end{array}$ & Yes & Yes & Yes & Yes & Yes & Yes \\
\hline
\end{tabular}

Table C3: Parameter estimates for models III-IV with test for significant policy's affecting wind power with a $15 \%$ depreciation rate to the wind power knowledge stocks and distance weighted stock. Covers the period $1990-2008$. R\&D flow.

\begin{tabular}{|c|c|c|c|c|c|c|}
\hline VARIABLES & 1 & 2 & 3 & 4 & 5 & 6 \\
\hline \multirow[t]{2}{*}{ R\&D-flow } & -0.00675 & -0.00970 & -0.00675 & -0.00970 & -0.00597 & -0.00639 \\
\hline & $(0.0230)$ & $(0.0236)$ & $(0.0230)$ & $(0.0236)$ & $(0.0231)$ & $(0.0237)$ \\
\hline \multirow{2}{*}{$\begin{array}{l}\text { Research } \\
\text { personnel }\end{array}$} & $0.132 * *$ & $0.157 * *$ & $0.132 * *$ & $0.157 * *$ & $0.135 * *$ & $0.165^{* * *}$ \\
\hline & $(0.0622)$ & $(0.0624)$ & $(0.0622)$ & $(0.0624)$ & $(0.0628)$ & $(0.0626)$ \\
\hline \multirow[t]{2}{*}{$\begin{array}{l}\text { National } \\
\text { stock }\end{array}$} & $-0.0630 * * *$ & & $-0.0630 * * *$ & & $-0.0611 * * *$ & \\
\hline & $(0.0168)$ & & $(0.0168)$ & & $(0.0175)$ & \\
\hline TRIPS & $\begin{array}{c}2.533 * * * \\
(0.123)\end{array}$ & $\begin{array}{c}2.310 * * * \\
(0.197)\end{array}$ & & & & \\
\hline \multirow{2}{*}{$\begin{array}{l}\text { Distance- } \\
\text { weighted } \\
\text { international } \\
\text { wind stock }\end{array}$} & & 0.0314 & & 0.0314 & & 0.0287 \\
\hline & & $(0.0595)$ & & $(0.0595)$ & & $(0.0594)$ \\
\hline EUETS & & & $\begin{array}{c}2.533 * * * \\
(0.123)\end{array}$ & & & \\
\hline FeedIn & & & & & $\begin{array}{l}-0.00119 \\
(0.00333) \\
\end{array}$ & $\begin{array}{l}-0.00449 \\
(0.00321) \\
\end{array}$ \\
\hline Wald chi2 & 4216 & 4216 & 4216 & 4216 & 4216 & 4216 \\
\hline Observations & 136 & 136 & 136 & 136 & 136 & 136 \\
\hline Log-likelihood & -383.61 & -385.81 & -383.61 & -385.81 & -383.60 & -385.88 \\
\hline Prob $>=$ chibar 2 & 0.000 & 0.000 & 0.000 & 0.000 & 0.000 & 0.000 \\
\hline $\begin{array}{l}\text { Time fixed } \\
\text { effects }\end{array}$ & Yes & Yes & Yes & Yes & Yes & Yes \\
\hline $\begin{array}{l}\text { Country Fixed } \\
\text { effects }\end{array}$ & Yes & Yes & Yes & Yes & Yes & Yes \\
\hline
\end{tabular}

Standard errors in parentheses

$* * * \mathrm{p}<0.01, * * \mathrm{p}<0.05, * \mathrm{p}<0.1$

Table C4: Parameter estimates for models VII-VIII with test for significant policy's affecting wind power with a $15 \%$ depreciation rate to the wind power knowledge stocks and distance weighted stock. Covers the period $1990-2008$. R\&D stock. 


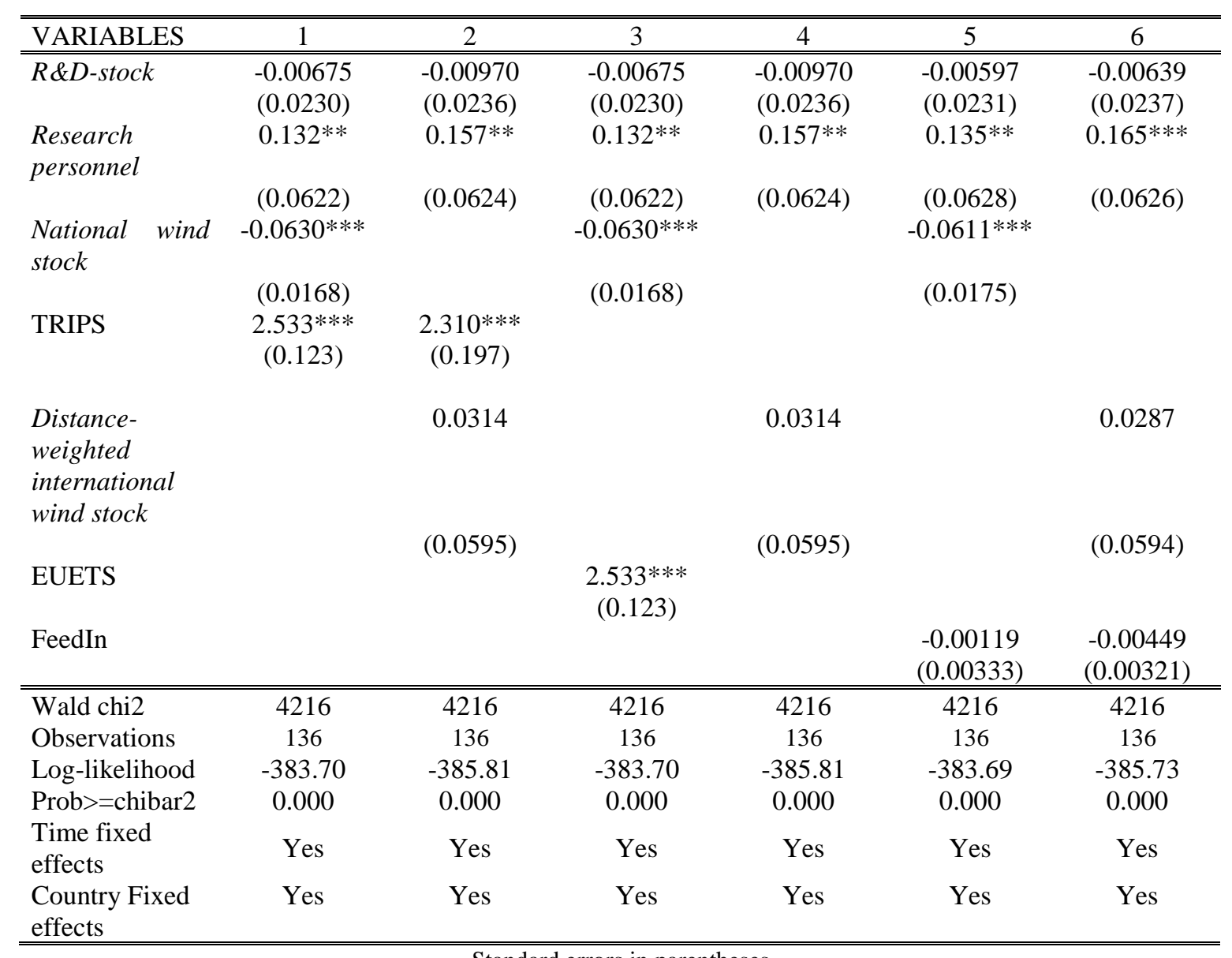

Standard errors in parentheses

$* * * \mathrm{p}<0.01, * * \mathrm{p}<0.05, * \mathrm{p}<0.1$ 